\title{
Linking corporate reputation and shareholder value using the publication of reputation rankings
}

\author{
Sven Tischer* \\ Lutz Hildebrandt*
}

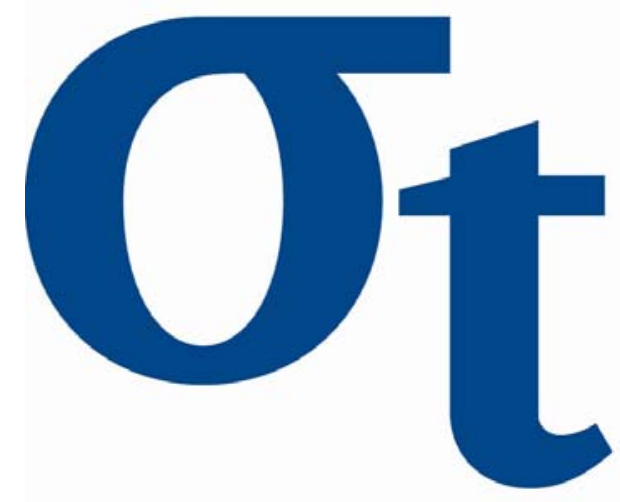

9)

$\checkmark$

6

* Humboldt-Universität zu Berlin, Germany

This research was supported by the Deutsche Forschungsgemeinschaft through the SFB 649 "Economic Risk". 


\title{
Linking corporate reputation and shareholder value using the publication of reputation rankings ${ }^{1}$
}

\author{
Sven Tischer and Lutz Hildebrandt ${ }^{2}$
}

\begin{abstract}
Good corporate reputation is seen as one of the most valuable assets. It is believed to cause a multitude of favorable impacts within different stakeholder groups. As a consequence, a multitude of studies analyzed the relationship between corporate reputation and financial performance. However, the most of them raised the question of causation due to their methodology. In order to isolate the impact of corporate reputation on financial performance, some authors had conducted event studies, but without any success. Therefore, this study provides a comprehensive theoretical background, why reputation has to affect financial performance. According to this theory, two event studies are conducted to analyze the impact of publishing reputation rankings of the German Manager Magazine from 1998 to 2008 on share prices. As expected, we find positive or negative announcement effects regarding upgraded or respectively downgraded companies. Consequently, investors gain new information from the published rankings (increase or decrease in reputation) to adjust share prices.
\end{abstract}

\section{Key words}

Corporate reputation, reputation ranking, financial performance, shareholder value, event study, portfolio study

\section{JEL Classification:}

M14, M31, G14, G11, C12, C13

\footnotetext{
${ }^{1}$ This research was supported by the Deutsche Forschungsgemeinschaft through the SFB 649 "Economic Risk". SFB 649, Humboldt-Universität zu Berlin, Spandauer Straße 1, D-10178 Berlin

${ }^{2}$ Humboldt-Universität zu Berlin, School of Business and Economics, Institute of Marketing, Spandauer Straße 1 , D-10178 Berlin,\{tischesv, hildebr\}@wiwi.hu-berlin.de
} 


\section{Introduction}

The major change in management research during the last decades is the paradigmatic move from thinking in tangible assets to intangibles (Barney, 1991). It is postulated that the intangible assets are the major drivers of sustainable performance because these assets cannot be easily neutralized by competitors, are hard to copy and in general not tradable via factor markets. As one of these factors, corporate reputation has become one of the most discussed (Abimbola \& Vallaster, 2007; Caruana, 1997; Hunt \& Morgan, 1995) and most valuable (Boot et al., 1993; Hall, 1992) intangibles. The latter point is attributed to the fact that reputation is considerably able to defend a competitive position (Jones et al., 2000; Dierickx \& Cool, 1989) especially by buffering negative critical incidents (Dhir \& Vinen, 2005). As a consequence we assume that a consistent and strong relationship between company reputation and financial performance exists. That implies that a relationship should also exist between information contained in corporate reputation rankings and financial performance.

A number of research studies have analyzed this relationship (Anderson \& Smith, 2006; Fornell, Mithas, Morgeson \& Krishnan, 2006; Inglis, Morley \& Sammut, 2006; Roberts \& Dowling, 2002; Rose \& Thomsen, 2004; Sanchez \& Satorrio, 2007; Vergin \& Qoronfleh, 1998 and), butnone of them were able to confirm, without any doubt, an influence of corporate reputation (measures) on financial performance. This is because either the analyses could not prove the claimed effects (Inglis et al., 2006; Rose \& Thomson, 2004) or the direction of causation (see also McGuire, Sundgren \& Schneeweis,1988; McGuire, Schneeweis \& Branch, 1990; Sabate \& Puente, 2003) could not definitely determined (Anderson \& Smith, 2006; Fornell et al., 2006; Roberts \& Dowling, 2002; Sanchez \& Satorrio, 2007; Vergin \& Qoronfleh, 1998).

In order to isolate the effect of reputation on financial performance, one can look for announcement effects of publishing reputation data as Hannon and Milkovich (1996), Ittner and Larcker (1998), Fornell, Mithas, Morgeson and Krishnan (2006) as well as Abraham, Friedman, Khan and Skolnik (2008) had done. However, these studies were unable to validate an impact of reputation announcements on shareholder value.

Therefore, we conduct an event study using a refined methodology and different data (reputation rankings). To examine the causal relationship, we investigate whether 
announcing significant positive (negative) changes of corporate reputation measures affect shareholder value positively (negatively). In contrast to the previous studies, we find a relationship as expected.

The paper is structured as follows. First, we develop the theoretical basis for our research by relating corporate reputation and shareholder value. This includes an overview of general drivers derived from financial and management theory, followed by a closer look at the specific (possible) impact of good reputation on shareholder value. After that, the information contained in published reputation rankings is shortly discussed and evaluated under the assumption of market efficiency. This is followed by a section with a detailed description of the event study methodology, the model we estimate and the used sample. Finally, the results are presented and discussed. The conclusion highlights the findings and limitations of our research.

\section{Theoretical basis}

\subsection{The concept of corporate reputation}

As a result of interdisciplinary initiated and driven research on corporate reputation and different perspectives ranging from psychology to management, a host of different concepts of reputation exist. Consequently, the need for a precise definition has long been claimed by Fombrun (1996) and Wartick (2002).

To date, it is broadly accepted that reputation is a collective construct which reflects an aggregated view of individual perceptions (Barnett, Jermier \& Lafferty, 2006; Walker, 2010; Wartick, 1992). According to Bromley (2002a), the collective is a relatively homogeneous group of people who partially share common interests in a reputational entity. Additionally, there is a general agreement that corporate reputation measurements have to be focused on the relevant stakeholders (Boulstridge \& Carrigan, 2000). Concerning measurement approaches, a distinction can be made between taking an overall perspective (Fombrun, 1996), including internal and external stakeholders; a stakeholder group-specific perspective (Bromley, 2002a); an issue-specific perspective, within different groups of stakeholders; and an overall issue-specific perspective (Walker, 2010). The question is not whether there are perceived differences between multiple stakeholder groups as shown in Figure 1 but rather to which extend. 
Figure 1: Key elements of corporate reputation and the corresponding information gaps (following Chun, 2005)

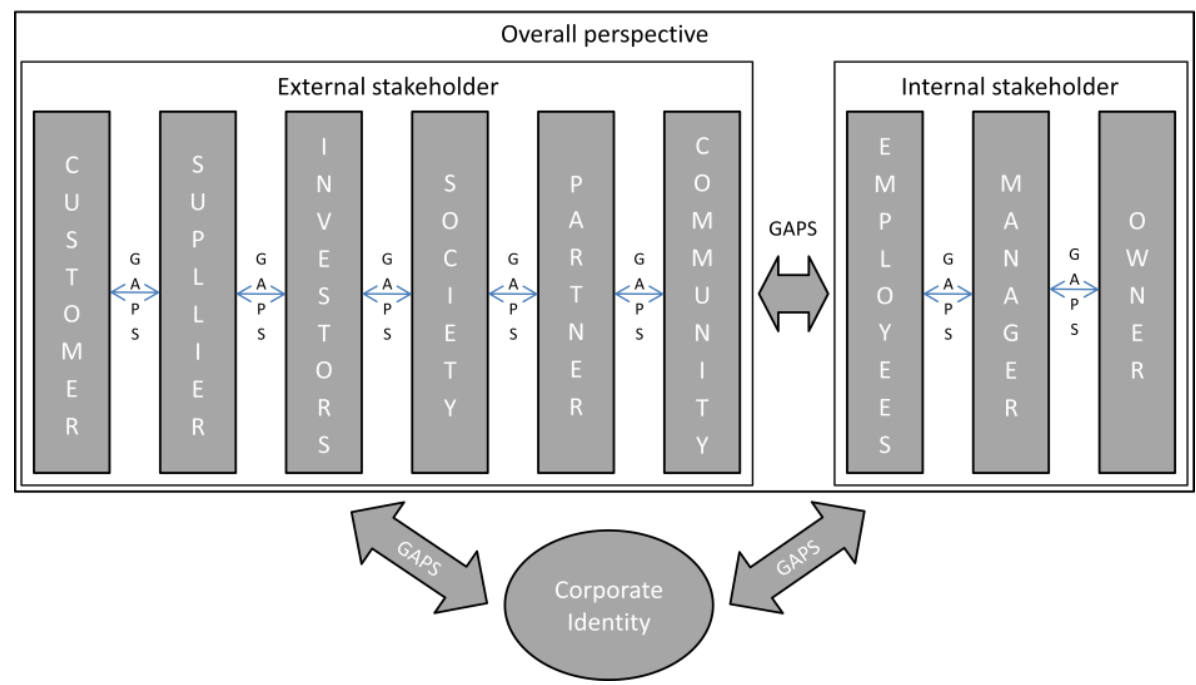

The Relational School (Chun, 2005) addresses this question by comparing the multiple stakeholder views. Based on information asymmetry between internal (insiders) and external stakeholders (outsiders), the perceptional gap between them should be most evident. Considering even the smaller differences between the groups within these two distinct groups, we define corporate reputation as:

A relatively stable, aggregated and indirectly suggestible perception within multiple stakeholder groups based on a company's past actions and future prospects in comparison to some reference.

In contrast to Walker's (2010) perspective, the issue-specific term is excluded due to the assumption that corporate reputation represents a simplified collective assessment. This assumption is supported by findings on the existence of haloeffects (Brown \& Perry, 1994; Schultz, Mouritsen \& Gabrielsen, 2001). However, our definition does not mean that an overall aggregation as stated by Fombrun (1996) is not acceptable. It emphasizes just the allowance of and not the need for variety in general. Indeed, the absence of such a variety could be attributed to considerations that an unfavorable reputation might contaminate a favorable one (Carter \& Deephouse, 1999) or vice versa. Furthermore, the empirical findings of Eberl and Schwaiger (2005) support the idea that corporate reputation between various stakeholder groups can be comparable. Attributed to these theoretical approaches and empirical findings, we assume that corporate reputation within one stakeholder group is in general an indication for the others. 


\subsection{Shareholder Value}

Taking a financial perspective, the economic value of a company is the sum of its debts and its equity. In the case of a publicly traded corporation, the value of equity portion is called shareholder value. According to Rappaport (1998), shareholder value is defined as the difference between the corporate value and its debts, whereas the corporate value reflects the present value of cash flows $(C F)$ generated by firm's operations during the forecast period and the residual value $(R)$ afterwards. Both cash flows and the residual value are uncertain expectations, which have to be estimated taking into account different states, their related probabilities and cash flows. An often proposed risk adjusted discount rate $(r)$ of these expectations is the weighted-average cost of capital (WACC) regarding a target capital structure (Rappaport, 1998). Thus, shareholder value (SV) is defined as:

$$
S V=\frac{C F_{1}}{(1+r)}+\frac{C F_{2}}{(1+r)^{2}}+\cdots+\frac{C F_{\tau}}{(1+r)^{\tau}}+\frac{R}{r(1+r)^{\tau}}-D e b t
$$

By dividing this resulting amount (SV) by the total number of issued shares, we will obtain the price per share. Using this model, share prices may be driven by financial decisions like share repurchase programs (Grullon \& Michaely, 2004; Stephen \& Weisbach, 1998), issues of new shares (Barclay \& Litzenberger, 1988) or changes in the capital structure (Masulis, 1980, 1983). Hence, it is essential for valid research to exclude such causes by assuming or rather checking that neither the number of issued shares nor the capital structure (debts) changes during an observation period. Taking that into account, three potential drivers of shareholder value are remaining. First, the cash flows $(C F)$ can be affected as illustrated in Figure 2. The cash flows can be both enhanced and accelerated. Accelerating cash flows increases the present value as a result of being less discounted, which is attributed to time and risk adjustments.

Second, changes of the discount rate $(r)$ will have an impact. Given that this interest rate has to compensate risks borne by debt holders and shareholders, a risk reduction would minimize the capital costs $(1+r)$. Consequently, the present value would shift in favor of the shareholders. In addition to accelerating cash flows, a risk reduction may be achieved by declining volatility and vulnerability of cash flows. 
The third remaining opportunity is to enhance the residual value $(R)$. However, all drivers have in common the fact that they are, solely or in sum, just a sufficient condition for affecting shareholder value.

Figure 2: Drivers of shareholder value, cash flows and risk (following Srivastava et al. 1998)
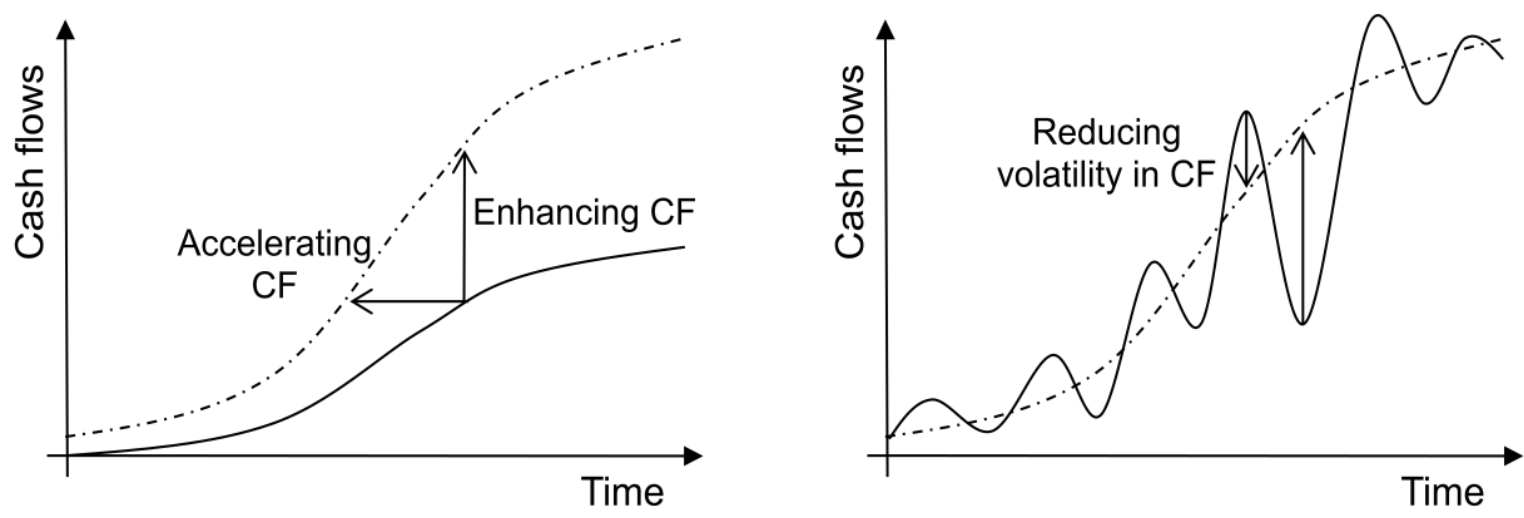

The necessary condition for an actual change is the demand of some investors, who are willing to purchase shares at a higher price than recently traded based on future expectations. After taking a glimpse at the individual potential drivers, the relationship between corporate reputation and these drivers is explained in the following chapter.

\subsection{How does reputation affect shareholder value?}

As stated by Barney (1991), a favorable corporate reputation can improve the competitive situation by positively influencing different stakeholder groups. However, this effect is claimed by some researchers to be the other way around (for an overview see Sabate \& Puente, 2003). Within the scope of this paper, we are focusing on corporate reputation as being the trigger. There are some studies which were able to support this view by showing positive effects of favorable reputation on financial performance (Dunbar \& Schwalbach, 2000; Eberl \& Schwaiger, 2005; Srivastava, Mclnish, Wood \& Capraro, 1997a). Building on our perspective on financial drivers, we differentiate stakeholder specific effects.

According to first financial driver, cash flows (CF) could be higher as well as accelerated by an earlier entry of stakeholders into a relationship with a company. Puncheva (2008) proposed and examined a signaling based framework where corporate reputation had a large influence in such a decision-making process. Reputation serves as a signal (Sabate \& Puente, 2003; Spence, 1974) and filter for all individuals without direct experience with an organization (Kazoleas, Kim \& Moffitt, 2001). In the same line, Kotha, Rajgopal and Rindova (2001) consider a good 
corporate reputation as a risk-reducing mechanism for customers. A comprehensive overview of recent studies on the informational, risk reduction value and other forces of reputation is given in Table 1.

Table 1: Mediating drivers, cash flow (external stakeholder)

\begin{tabular}{|c|c|c|}
\hline Stakeholder & Good corporate reputation... & References \\
\hline \multirow[t]{4}{*}{ Customer: } & Is used as a risk-reduction mechanism & $\begin{array}{l}\text { Goldberg \& Hartwick, 1990; } \\
\text { Kotha et al., 2001; Lafferty \& } \\
\text { Goldsmith, } 1999\end{array}$ \\
\hline & Influences buying intentions & Yoon et al., 1993 \\
\hline & Leads to higher product prices & $\begin{array}{l}\text { Deephouse, 2000; Klein \& Leffler, } \\
\text { 1981; Landon \& Smith, 1997; } \\
\text { Podolny, 1993; Rindova et al., } \\
\text { 2005; Shapiro, 1983; }\end{array}$ \\
\hline & Increases repurchase & Shapiro, 1983 \\
\hline \multirow[t]{4}{*}{ Supplier: } & Reduces transaction costs & $\begin{array}{l}\text { Bromley, 2002b; Kotha et al., 2001; } \\
\text { Williamson, } 1985\end{array}$ \\
\hline & $\begin{array}{l}\text { Attracts better suppliers and increases } \\
\text { their loyalty }\end{array}$ & Podolny, 1993 \\
\hline & $\begin{array}{l}\text { May reduce contracting and monitoring } \\
\text { costs }\end{array}$ & Roberts \& Dowling, 2002 \\
\hline & $\begin{array}{l}\text { Can lead to an anticipation of a long } \\
\text { term relationship }\end{array}$ & Groenland, 2002 \\
\hline Investors: & $\begin{array}{l}\text { Enables easy access to more capital } \\
\text { with less effort }\end{array}$ & $\begin{array}{l}\text { Dhir \& Vinen, 2005; } \\
\text { Schwalbach, } 2000\end{array}$ \\
\hline
\end{tabular}

Almost all of the discovered effects can be attributed to the signal function of corporate reputation resulting from the lack of knowledge. Only increasing repurchases and higher product prices, as referred to by Shapiro (1983), are due to individual acceptance of and identification with an organization as a result of actual positive experiences. With the exception of attracting top employees, the latter statement fits as well for the mediating cash flow drivers of internal stakeholders (e.g. employees, see Table 2). All of them have in common that they are minimizing the costs and consequently the out flowing cash.

Table 2: Mediating drivers, cash flow (internal stakeholder)

\begin{tabular}{lll} 
Stakeholder & Good corporate reputation... & References \\
\hline Employees: & $\begin{array}{l}\text { Indicates a company's ability to attract } \\
\text { top employees }\end{array}$ & $\begin{array}{l}\text { Turban \& Greening, 1997; } \\
\text { Winkleman, 1999 }\end{array}$
\end{tabular}


Leads to more loyal behavior

Reduces personnel fluctuation

Fombrun, 1996

Caminiti, 1992; Dowling, 1986;

Eidson \& Master, 2000; Nakra, 2000; Preece et al., 1995; Roberts

\& Dowling, 2002; Winkleman, 1999

Increases morale \& productivity

Related to the second driver, the discount rate $(r)$, investors are in the center of attention. They are used to assess companies on the basis of their economic risks. Here corporate reputation may signal a lower probability of becoming insolvent or bankrupt. This lower risk perception can be the result of profitability (Dowling, 2006) derived from the positive cash flow drivers and less sales variance (Srivastava et al., 1997b; Dowling, 2006). Both reasons are substantially attributed to a stable customer base as with the residual value drivers specified below. Additionally, Dowling (2006) suggested the credit rating as a cause of risk reduction. Finally, lower borrowing costs reduce the weighted-average cost of capital (WACC) or rather the discount rate.

Table 3: Mediating drivers, cost of capital (all stakeholders)

\begin{tabular}{lll} 
Stakeholder & Good corporate reputation... & References \\
\hline Investors: & Reduces costs of capital & Beatty \& Ritter, 1986 \\
& Leads to as less risky perceived & Orlitzky \& Benjamin, 2001; \\
& investments & Srivastava et al., 1997a \\
& Influences the investment decision & Little \& Little, 2000; Lucey \& \\
positive & Dowling, 2005; McGregor et al., \\
& & 2000; Shefrin, 2001;
\end{tabular}

Furthermore, in the case of good reputation and an intended brand extension, Dowling (2006) stated the opportunity of leveraging revenues related to growth. From a different perspective, this can be interpreted as a reduction in risk as well as being based on a loyal and stable customer base. The customer base is assigned to the third shareholder value driver - residual value. This loyal base is generated and growing by satisfied customers. Both Aaker (1991) and Grewal, Krishnan, Baker and Borin (1998) pointed out that a good reputation enhances perceived quality and consequently satisfaction. But the following mediation drivers of residual value also influence both cash flow and discount rate drivers. For example, high customer loyalty reduces sensitivity to price rises and the effect of special offers by competitors 
(Hallowell, 1996). On the one hand this causes higher cash flows (CF) and on the other hand it reduces risks $(r)$ by lowering the vulnerability of cash flows.

Table 4: Mediating drivers, residual value (all stakeholders)

\begin{tabular}{|c|c|c|}
\hline Stakeholder & Good corporate reputation... & References \\
\hline \multirow[t]{5}{*}{ Customer: } & Enhances perception of quality & Grewal et al., 1998 \\
\hline & $\begin{array}{l}\text { Leads to higher post-purchase and post- } \\
\text { use satisfaction }\end{array}$ & $\begin{array}{l}\text { Aaker, 1991; } \\
\text { Lafferty \& Goldsmith, } 1999\end{array}$ \\
\hline & Increases loyalty & $\begin{array}{l}\text { Lafferty \& Goldsmith, 1999; } \\
\text { Nguyen \& Leblanc, } 2001\end{array}$ \\
\hline & Leads to higher customer retention & $\begin{array}{l}\text { Caminiti, 1992; Landon \& Smith, } \\
\text { 1997; Preece et al., 1995; Selnes, } \\
1993\end{array}$ \\
\hline & $\begin{array}{l}\text { Enlarges customer basis, fewer leave } \\
\text { and more arrive }\end{array}$ & Rogerson, 1983 \\
\hline
\end{tabular}

If we follow the presented framework then a good reputation will affect the shareholder value. Anderson and Smith (2006) as well as Freiesleben (2006) have indirectly proven the relationship by showing a positive effect of good corporate reputation on pricing. Furthermore, Cooper, Dimitrov and Rau (2001) worked out that investors were willing to pay higher prices even if reputation ("dotcom effect") did not influence firm profitability.

But if we take this impact as accepted in general, the next question which comes to mind is how corporate reputation is reflected in share prices. We will address this in the next section.

\subsection{How do share prices reflect the status of companies' reputations?}

Based on Fama's $(1970,1991)$ classification of market efficiency, we assume a semistrong market efficiency, which means that all public information are "fully" reflected by share prices. Nevertheless, there are still two different perspectives remaining on how reputation has been reflected.

The first perspective is that share prices "fully" reflect corporate reputation continually. This approach is based on the assumptions that market participants can observe every positive or negative event which influences reputation, are able to adjust their expectations appropriately and take part in setting prices. However, in spite of assuming a perfect capital market, there is no need for homogeneous expectations of all market participants to drive prices. It will be sufficient in the 
process if some investors who are solvent enough gain the same expectation (Seeger, 1998). As a consequence, share prices are always adjusted.

Nevertheless, due to the characteristics of corporate reputation, it is doubtful that market participants are able to set appropriate prices. That is because, on the one hand, collective opinions and perceptions of stakeholders who are not invested are not public information. On the other hand, corporate reputation is only informative in comparison to the perception of competitors.

Consequently, the second perspective is that corporate reputation has to be explicitly published to be "fully" reflected in share prices. A publication of quantified reputation rankings seems to be the best way to obtain information about the actual reputation. Following Fornell et al. (2006) or rather Ittner and Larcker (2003), this perspective can additionally be justified by high expenses for investors which would result from individually conducted surveys as well as the use of a sophisticated measurement technology. As a consequence, due to exceeding or falling below the expectations of market participants, a ranking publication can lead to a strong market reaction. This reaction would be in compliance with findings from the publication of other significant variables like revenues or earnings (Landsman \& Maydew, 2002; Cornell \& Landsman, 1989; Aharony \& Swary, 1980). Based on the second perspective, the following question arises to be studied.

\subsection{How to measure the effect of publishing reputation rankings on share prices?}

This question can be analyzed following two distinct lines of approach. On the one hand, one could look for a relationship between companies which were awarded within a reputation ranking and their financial performance in the long run. In this case, both analyses which could (Anderson \& Smith 2006; Fornell et al., 2006; Roberts \& Dowling, 2002; Sanchez \& Satorrio, 2007; Vergin \& Qoronfleh, 1998) and which could not (Inglis et al., 2006; Rose \& Thomsen, 2004) verify the linkages exist. On the other hand, one could look for significant short term response generated by the announcement. In this case, the causal relationship would be more evident. A directly observable effect results from the announcement of quantified reputation measures. In contrast to the first line of approach, the empirical findings on announcement effects are unambiguous to date. Despite various subjects of examination (see Chapter 6), the assessments of Hannon and Milkovich (1996), Fornell et al. (2006) and Abraham et al. (2008) could not validate an effect. The 
authors of these studies justified consistently the absence of an announcement effect by existing market efficiency as explained in the previous chapter as option one (Abraham et al., 2008; Fornell et al., 1996; Hannon \& Milkovich, 1996). That is, the ranking in its aggregated form "fully" reflects all historical events and knowledge as well as the share price. In short, publication of the ranking offered no new information for possible investors.

Assuming that the previously presented theory of adjusting expectations and consequently share prices as result of adapting publicized reputation data is more likely, we conduct the study below.

\section{Methodology}

The objective of our event study is to examine whether announcing a considerable change in reputation causes a significant increase or decrease in share prices. We assume the existence of efficient capital markets, no confounding events and unanticipated information until the day of announcement for the estimation and the specification of the event window. The smallest event window includes just the day of publication with $\tau=0$. But, this window is usually specified larger to encompass also possible effects before and after the public announcement which could be caused by the information. Following Fama (1970, 1991) and McWilliams and Siegel (1997), all the used event windows fulfill sufficiently assumed semi-strong information efficiency. The largest event window includes three days - the event day, the day before and the day after. The previous day $(\tau=(-1))$ should usually cover share trades which could be based on a leakage of information (McWilliams \& Siegel, 1997). In contrast, the day after $(\tau=(+1))$ should take into account both delayed reactions rather than reactions of early followers and the fact that information can be obtained by market participants after the stock market closes. In general the event window is defined as $\tau=\mathrm{T}_{1}+1$ to $\mathrm{T}_{2}$ (MacKinlay, 1997). The windows should not overlap to avoid an influence on estimators through returns around the event. Hence, the estimation window is defined as $\tau=T_{0}+1$ to $T_{1}$ (MacKinlay, 1997).

Figure 3: Time line for an event study (MacKinlay, 1997)

Estimation window


Figure 3 illustrates the timing sequence including the post-event window to obtain a general overview. Four different event windows are examined. The first window covers just the event day, whereas the second one includes additionally the day after the announcement. The third and fourth examined windows start one day prior to the disclosure. The fourth one is the largest examined event window which includes the day afterwards as well. Consequently, depending on the size of the event window, the estimating period of the four mentioned windows ends in $\mathrm{T}_{1}=(-2)$ or in $\mathrm{T}_{1}=$ $(-1)$ as shown in Figure 4.

Figure 4: The four examined event windows

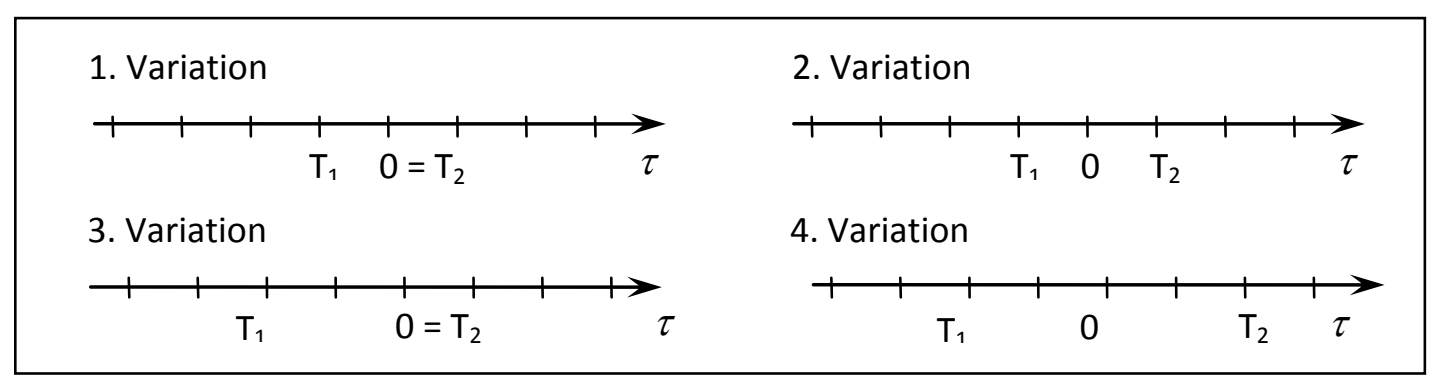

To validate our results, another larger window is calculated to check whether the portfolios are more uniformly performing beyond the maximum period of three days. This window is spanned from three days prior to three days after the publication. The length of the estimation window is set to 150 trading days in all variations.

The financial effects are indicated by abnormal returns $A R_{i, \tau}$. Returns are indexed in time and in companies using $\tau$ and $i$. The analytical course including the equations follows the study of MacKinlay (1997). The abnormal returns are defined as the difference between the actual ex-post returns $R_{i, \tau}$ and the "normal" returns $E\left(R_{i, \tau} \mid X_{\tau}\right)$ as shown in the following equation:

$$
A R_{i, \tau}=R_{i, \tau}-E\left(R_{i, \tau} \mid X_{\tau}\right) \text { assuming that } E\left(R_{i, \tau} \mid X_{\tau}\right) \sim N\left(\mu_{i}, \sigma_{i}^{2}\right) .
$$

$X_{\tau}$ symbolizes the condition that the "normal" return is the ex-ante expected return without anticipating the event at $\tau=0$. The "normal" returns are estimated with a linear regression based on the actual ex-post returns for the whole period beginning at $\mathrm{T}_{0}+1$ and ending at $\mathrm{T}_{1}$. Actual ex-post returns could be calculated on the basis of both discrete and continuously compounded returns. If the price of a security is declared as $P_{i, \tau}$ at time $\tau$, then discrete returns and logarithmic returns are defined as presented in the equations below. 
(3) $\quad r_{i, \tau}=\frac{P_{i, \tau}}{P_{i, \tau-1}}-1$

(4) $\quad R_{i, \tau}=\ln \left(1+r_{i, \tau}\right)=\ln \left(\frac{P_{i, \tau}}{P_{i, \tau-1}}\right)=\ln \left(P_{i, \tau}\right)-\ln \left(P_{i, \tau-1}\right)$

Defining the continuously compounded returns as $R_{i, \tau}$, we assume normally distributed logarithmic returns during the analysis which means that the discrete returns are log-normally distributed (see equation 4). Thus,

(5) $\quad R_{i, \tau} \sim N\left(\mu_{i}, \sigma_{i}^{2}\right)$,

(6) $\quad E\left(r_{i, \tau}\right)=e^{\mu_{i}+\frac{\sigma_{i}^{2}}{2}}-1$ and

(7) $\quad \operatorname{VAR}\left(r_{i, \tau}\right)=e^{2 \mu_{i}+\sigma_{i}^{2}}\left(e^{\sigma_{i}^{2}}-1\right)$.

However, this is in contrast to the classical assumption of the Capital Asset Pricing Model (CAPM) from Sharpe (1964), Lintner (1965) and Mossin (1966) as shown in equation (8), which assumes discrete returns to be normally distributed. But there are two advantageous points in doing so. On the one hand, log-normally distributed discrete returns are limited to -1 resulting in a minimum gross return $\left(1+r_{i, \tau}\right)$ of zero and consequently a maximum loss of $100 \%$. On the other hand, logarithmic returns can be easily summed up over multiple periods.

$$
R_{i, \tau}=R_{f, \tau}+\beta_{i}\left(R_{m, \tau}-R_{f, \tau}\right)
$$

$R_{f, \tau}$ corresponds to the risk free rate of return and $R_{m, \tau}$ to the return of the market. The difference between both is known as risk premium. Due to the fact that both market return and riskless return are not observable, approximating indices will be used. The procedures of computing corresponding returns are analogous to security prices. Therefore, we assume:

$$
R_{m, \tau} \sim N\left(\mu_{m}, \sigma_{m}^{2}\right) \text { and } R_{f, \tau} \sim N\left(\mu_{f}, \sigma_{f}^{2}\right) .
$$

Transforming equation (8) to the empirical Sharpe-Lintner equilibrium, which we used to estimate the $\beta_{i}$ parameters, shows that individual risk premium equals risk premium times $\beta_{i}$ :

$$
R_{i, \tau}-R_{f, \tau}=\beta_{i}\left(R_{m, \tau}-R_{f, \tau}\right)+\varepsilon_{i, \tau}
$$


For the validity of this equation it will be assumed that:

$$
E\left(\varepsilon_{i, \tau}\right)=0, \sigma^{2}\left(\varepsilon_{i, \tau}\right)=\sigma_{\varepsilon_{i}}^{2} \quad \text { and } \operatorname{Cov}\left(\varepsilon_{j}, \varepsilon_{k}\right)=0 \quad \text { for } j \neq k
$$

as well as stationary of parameters $\boldsymbol{\beta}_{\boldsymbol{i}}$ (Seyhun, 1986, Seeger, 1998). After using the Sharpe-Lintner equilibrium to estimate the $\boldsymbol{\beta}$ parameters, the next steps to calculate average abnormal returns are as stated below.

$$
\begin{aligned}
& A R_{i, \tau}=R_{i, \tau}-\left(R_{f, \tau}+\hat{\beta}_{i}\left[R_{m, \tau}-R_{f, \tau}\right]\right) \\
& \overline{A R_{\tau}}=\frac{1}{n} \sum_{i=1}^{n} A R_{i, \tau}
\end{aligned}
$$

After adding up the abnormal returns of all companies on a given day, finally the calculation of the cumulative average abnormal return $\overline{C A R}\left(\tau_{1}, \tau_{2}\right)$ follows with a defined event window of $\tau_{1}$ to $\tau_{2}$ and $\mathrm{T}_{1}<\tau_{1} \leq \tau_{2} \leq \mathrm{T}_{2}$ :

$$
\overline{C A R}\left(\tau_{1}, \tau_{2}\right)=\sum_{\tau_{1}}^{\tau_{2}} \overline{A R_{\tau}} .
$$

Depending on whether a portfolio of positive announcements, related to an increase of reputation, or a portfolio of negative announcements the corresponding null hypotheses to be tested are:

$$
H_{0}^{+}: \overline{C A R}\left(\tau_{1}, \tau_{2}\right) \leq 0 \quad \text { and } \quad H_{0}^{-}: \overline{C A R}\left(\tau_{1}, \tau_{2}\right) \geq 0
$$

The resulting alternative hypotheses are:

$$
H_{1}^{+}: \overline{C A R}\left(\tau_{1}, \tau_{2}\right)>0 \text { and } H_{1}^{-}: \overline{C A R}\left(\tau_{1}, \tau_{2}\right)<0 .
$$

Following the null hypotheses and the related assumption that the investigated events do not influence the expected value or the variance, a normal distribution of $\boldsymbol{A R}_{\boldsymbol{i}, \boldsymbol{\tau}}$ will be supposed and Students t-test could be applied in the following form:

$$
\Theta=\frac{\overline{C A R}\left(\tau_{1}, \tau_{2}\right)}{\sqrt{\widehat{\sigma}^{2}\left(\overline{C A R\left(\tau_{1}, \tau_{2}\right)}\right)}} \sim N(0,1) .
$$

The data for this analysis and its related adjustments are presented in the following section. 


\section{Sample}

The required sample to analyze the announcement effect of reputation rankings consists of quantified corporate reputation data and price data of the corresponding stocks and indices.

In the case of reputation data, we take advantage of the rankings from the German periodical Manager Magazin. ${ }^{3}$ Manager Magazin published reputation rankings during 1992-2008 in a two-year cycle. Rankings are used from 1998 to 2008 because in 1998 the measurement model was changed. ${ }^{4}$ According to Manager Magazin, within the ten-year time span a sample of 2,500 representatively chosen senior executives were surveyed by phone for every published ranking. These respondents were randomly chosen out of a pool of almost 500,000 executives from 17 different sectors and various types of companies. The interviews took place over a one-month period between August and October of the previous year. In this process, every expert had to assess around 40 companies regarding their reputation. The assessment was done on an aggregated level using an eleven-point rating scale from 0 (very bad) to 10 (very good). Using these ratings, the mean values of all companies were calculated and presented in a descending order in the ranking. In addition to that, all jurors were always asked for their opinion what the key characteristics of corporate reputation are.

Table 5: Key characteristics of corporate reputation (Manager Magazin)

\begin{tabular}{|l|c|c|c|c|c|c|c|}
\hline Year & \multicolumn{1}{|c|}{1996} & 1998 & 2000 & 2002 & 2004 & 2006 & 2008 \\
\hline Customer orientation & u. & 1 & 1 & 1 & 1 & 1 & 1 \\
\hline Product and service quality & u. & 2 & 2 & 2 & 2 & 2 & 2 \\
\hline Quality of management & 2 & 3 & 3 & 3 & 3 & 3 & 3 \\
\hline Innovativeness & 4 & 5 & 4 & 4 & 4 & 4 & 4 \\
\hline Price-performance ratio & 1 & 4 & 6 & 5 & 5 & 5 & u. \\
\hline Communication services & 6 & 7 & 5 & 6 & 6 & 6 & u. \\
\hline Employee orientation & 5 & 6 & 7 & 7 & 7 & 7 & u. \\
\hline Financial power & 3 & 8 & 8 & 8 & 8 & 8 & u. \\
\hline Attractiveness for managers & 9 & 11 & 10 & 9 & 9 & 9 & u. \\
\hline Internationalization & & 10 & 9 & 10 & 10 & 10 & u. \\
\hline Environmental responsibility & 7 & 9 & 12 & 11 & 12 & 12 & u. \\
\hline Growth dynamic & 8 & 12 & 11 & 12 & 11 & 11 & u. \\
\hline
\end{tabular}

Note: graded by frequency of occurrence (u. - undisclosed)

\footnotetext{
3 The distribution range per issue is approximately 688,000 readers and includes $69 \%$ of executives and managers in Germany (Media Spiegel, Feb. 2009, http://www.spiegelgruppe-nachdrucke.de/internet/mediaeng.nsf)

${ }^{4}$ Furthermore, one could see a major change in response of what was deemed to be relevant for corporate reputation before 1998 (see table 5).
} 
The responses, listed and graded in accordance to the frequency of occurrence in Table 5, are quite stable within the period under investigation.

Based on detailed results from 2006, this rank order is highly correlated with the influence of these factors. Because of analyzing announcement effects in connection with quantified changes in corporate reputation, five testable events result from the six rankings.

During the years 2000 to 2008, the reputation rankings were published by an official awarding, via internet and in the press. The simultaneous publication via internet and press followed the awarding by several days. We conducted internet research to specify the day of official awarding, which we used as event day $(\tau=0)$. This research was extended to check for firm specific confounding events such as announcements of future capital actions (Barclay \& Litzenberger, 1988; Grullon \& Michaely, 2004; Masulis, 1980, 1983; Stephen \& Weisbach, 1998), modifications of dividend policy (Aharony \& Swary, 1980) or relevant accounting figures (Landsman \& Maydew, 2002) during all examined event windows.

On the basis of the six reputation rankings, which contain 856 assessments, the sample is first adjusted to contain just the German enterprises. The decisions are based on the location of the corporate headquarters. In the course of further adjustments, not listed companies, companies for which confounding events are identified and illiquid securities are excluded. We categorized an asset as illiquid if the shares were not traded on more than one trading day during the period of interest. These illiquid securities have to be rejected because these securities could react strongly, even at a small trading volume, which could lead to biased results. The rejection of these securities is also important because of their heavy violation of the assumption of a perfect capital market, which includes that all assets are tradable anytime. For the remaining companies, the percentage deviation is calculated using their respective reputation score and the arithmetic average of all initially included companies within the corresponding year. The overall average corresponds to one hundred percent. The comparison of relative values is preferable due to fluctuating overall averages within the six rankings (see Table 6 ). ${ }^{5}$

\footnotetext{
5 The mean value of all ratings regarding the company is calculated and rounded to two decimal places. This result is multiplied by 100 . Consequently, the maximum score is 1000 .
} 
Table 6: Distribution of reputation measures (Manager Magazin)

\begin{tabular}{|c|c|c|c|c|c|c|}
\hline Year & 1998 & 2000 & 2002 & 2004 & 2006 & 2008 \\
\hline Best & 851 & 853 & 864 & 882 & 910 & 893 \\
& $\ldots$ & $\ldots$ & $\ldots$ & $\ldots$ & $\ldots$ & $\ldots$ \\
Mean & 650 & 649 & 644 & 644 & 657 & 668 \\
& $\ldots$ & $\ldots$ & $\ldots$ & $\ldots$ & $\ldots$ & $\ldots$ \\
Worst & 482 & 457 & $356^{*}$ & 428 & 494 & 491 \\
\hline
\end{tabular}

* Outlier, not listed, restructured and partly sold after a scandal, next rank 418

The fluctuating effects could be attributable to a more positive or negative general perception caused by a strong economy as opposed to a recession. Consequently, these effects could bias both the selection and the results. After comparing the calculated percentage deviations of two consecutive rankings, all companies were excluded where the corresponding difference between these relative positions is smaller than $4 \%$. This threshold value is based on the statement in Manager Magazin that a difference of corporate reputation is only perceivable if the reputation measure differs by at least 15 points. According to the goal of this study to examine the announcement effect of changes in quantified corporate reputation published via ranking, the final sample should include only perceivable changes. This condition is fulfilled by a threshold of $4 \%$, even for the weakest listed companies (see Table 6).

The remaining 93 changes in reputation measures are split into two portfolios. One portfolio contains the upgrades whereas the other one contains the downgrades. $A$ final adjustment of the sample is based on the assumption of the used CAPM - that the $\beta$ parameter should reflect the company specific risk in comparison to the market return. But some $\beta$ parameter estimators were not significant at a significance level of 0,01 ( $p$-value). Consequently, they were excluded and 88 remaining changes of reputation included 41 upgrades and 47 downgrades $^{6}$.

The required price data of shares and indices are extracted from the financial database Datastream. To calculate the logarithmic returns of shares according to Equation 6, the adjusted and unpadded share prices ${ }^{7}$ are used as $P_{i, \tau}$. These prices on Datastream are the official closing prices from the Frankfurt Stock Exchange $\left(\mathrm{FWB}^{\circledR}\right)$ which are adjusted for subsequent capital actions.

\footnotetext{
${ }^{6}$ For an overview of the final sample see appendix.

${ }^{7}$ Datatype (P\#T)
} 
As approximation of market returns $R_{m, \tau}$ is the $\mathrm{CDAX}{ }^{\circledR}$ used. This index contains all German shares which are listed in the General Standard and Prime Standard on the $\mathrm{FWB}^{\circledR}$ and measures the performance of the entire German equities market. As approximation of riskless returns $R_{f, \tau}$, the $\mathrm{REX}{ }^{\circledR}$ is used. This weighted index is a representative sample of the German government bond market. The index is calculated on the basis of 30 domestic bonds and considers various times to maturity (one to ten years) as well as three interest rates. ${ }^{8}$ The $\mathrm{CDAX}^{\circledR}$ and the REX ${ }^{\circledR}$ are both computed by Deutsche Börse and listed twice on $\mathrm{FWB}^{\circledR}$. In both cases the price indices adjusted for capital changes are used in this study.

\section{Results}

The average abnormal returns $\overline{A R}_{\tau}$ as well as the accumulation of them $\overline{C A R}\left(\tau_{1}, \tau_{2}\right)$ are presented below, shown as percentages. The corresponding $\mathrm{p}$-values are determined for one-tailed t-tests. In both samples, the cumulated average returns are as expected. The positive announcements regarding a significant increase of corporate reputation induce positive $\overline{C A R}\left(\tau_{1}, \tau_{2}\right)$.

Table 7: Empirical results, upgraded companies

\begin{tabular}{|c|c|c|c|c|c|}
\cline { 2 - 6 } \multicolumn{1}{c|}{} & \multicolumn{5}{c|}{ Upgraded $(\mathrm{n}=41)$} \\
\hline$\overline{A R}_{\tau-3}$ & - & - & - & - & 0.268 \\
\hline$\overline{A R}_{\tau-2}$ & - & - & - & - & 0.451 \\
\hline$\overline{A R}_{\tau-1}$ & - & - & 1.063 & 1.063 & 1.083 \\
\hline$\overline{A R}_{\tau=0}$ & 0.383 & 0.383 & 0.386 & 0.386 & 0.490 \\
\hline$\overline{A R}_{\tau+1}$ & - & -0.265 & - & -0.272 & -0.419 \\
\hline$\overline{A R}_{\tau+2}$ & - & - & - & - & -0.001 \\
\hline$\overline{A R}_{\tau+3}$ & - & - & - & - & 0.222 \\
\hline$\overline{C A R}_{\left.\tau_{1}, \tau_{2}\right)}$ & 0.383 & 0.118 & 1.449 & 1.177 & 2.094 \\
\hline $\mathrm{t}$-value & 1.435 & 0.313 & 3.859 & 2.559 & $*$ \\
\hline p-value & 0.079 & 0.378 & 0.000 & 0.006 & $*$ \\
\hline
\end{tabular}

* Control window, not tested due to violating the assumptions of efficient capital markets

In contrast, the releases of a decreasing reputation induce negative cumulated average returns. However, the effects are not significant for all event windows. It is striking that the $\overline{\mathrm{CAR}}\left(\tau_{1}, \tau_{2}\right)$ regarding the positive announcements are significant in

\footnotetext{
${ }^{8}$ CDAX $^{\circledR}$ : Performance index (ISIN: DE0008469115) and Price index (ISIN: DE0008469107)

REX $^{\circledR}$ : Performance index (ISIN: DE0008469602) and Price index (ISIN: DE0008469800)
} 
three out of four cases, whereas the negative announcements are only significant in the smallest event window $(\tau=0)$. Furthermore, it was unexpected that in both samples on the day following the event $(\tau=(+1))$, the sign of $\overline{A R}_{\tau}$ is opposite to that of the event day itself $(\tau=0)$. It can be supposed that this effect signals that these companies are temporarily less or more risky for investors, depending on whether they are up- or downgraded respectively. This would be in line with findings on the post-earnings-announcement drift of Bernard and Thomas (1989).

Table 8: Empirical results, downgraded companies

\begin{tabular}{|c|c|c|c|c|c|}
\cline { 2 - 6 } \multicolumn{1}{c|}{} & \multicolumn{5}{c|}{ Downgraded $(\mathrm{n}=47)$} \\
\hline$\overline{A R}_{\tau-3}$ & - & - & - & - & 0.279 \\
\hline$\overline{A R}_{\tau-2}$ & - & - & - & - & 0.347 \\
\hline$\overline{A R}_{\tau-1}$ & - & - & 0.386 & 0.386 & 0.380 \\
\hline$\overline{A R}_{\tau=0}$ & -0.773 & -0.773 & -0.772 & -0.772 & -0.802 \\
\hline$\overline{A R}_{\tau+1}$ & - & 0.297 & - & 0.293 & 0.334 \\
\hline$\overline{A R}_{\tau+2}$ & - & - & - & - & 0.315 \\
\hline$\overline{A R}_{\tau+3}$ & - & - & - & - & 0.177 \\
\hline$\overline{C A R}_{\left.\tau_{1}, \tau_{2}\right)}$ & -0.773 & -0.477 & -0.386 & -0.093 & 1.030 \\
\hline $\mathrm{t}$-value & -2.745 & -1.196 & -0.971 & -0.191 & ${ }^{*}$ \\
\hline $\mathrm{p}$-value & 0.004 & 0.117 & 0.167 & 0.424 & ${ }^{*}$ \\
\hline
\end{tabular}

* Control window, not tested due to violating the assumptions of efficient capital markets

The overall adjusted $R^{2}$ of the parameter estimations is 0.341 . Due to the clear differences between the $\overline{C A R}\left(\tau_{1}, \tau_{2}\right)$ of both samples, significance of these differences is tested additionally. Considering the different sample sizes as well as the possibly different variances, we run Welch's t-test (Sawilowsky, 2002). The results of using a two-tailed t-test are reported in Table 9, which shows that the differences are only significant for two event windows: the event day itself $\left(\tau_{0}\right)$ and the window including additionally the day before $\left(\tau_{-1}\right.$ to $\left.\tau_{0}\right)$.

Table 9: Results of Welch's t-test

\begin{tabular}{|c|c|c|c|c|}
\cline { 2 - 5 } \multicolumn{1}{c|}{} & $\tau_{0}$ & $\tau_{0}$ to $\tau_{+1}$ & $\tau_{-1}$ to $\tau_{0}$ & $\tau_{-1}$ to $\tau_{+1}$ \\
\hline Delta $^{*}$ & 1.156 & 0.595 & 1.835 & 1.270 \\
\hline t-value & 2.415 & 1.042 & 2.302 & 1.598 \\
\hline p-value & 0.018 & 0.301 & 0.024 & 0.114 \\
\hline \multicolumn{4}{c}{${ }^{*} \overline{C A R}\left(\tau_{1}, \tau_{2}\right)^{\text {Upgraded }}-\overline{C A R}\left(\tau_{1}, \tau_{2}\right)^{\text {Downgraded }}$}
\end{tabular}

As a result, the impact of the announcement is once again confirmed at the event day. Furthermore, the second significant difference $\left(\tau_{-1}\right.$ to $\left.\tau_{0}\right)$ indicates, combined with the results of Table 7, 8 and Figure 5, a leakage of information prior to the public 
announcements. Apart from that, the calculation of exceeding returns for the control window shows that the returns of the two distinct portfolios are more in balance beyond the examined event windows (Figure 5).

Figure 5: Control window

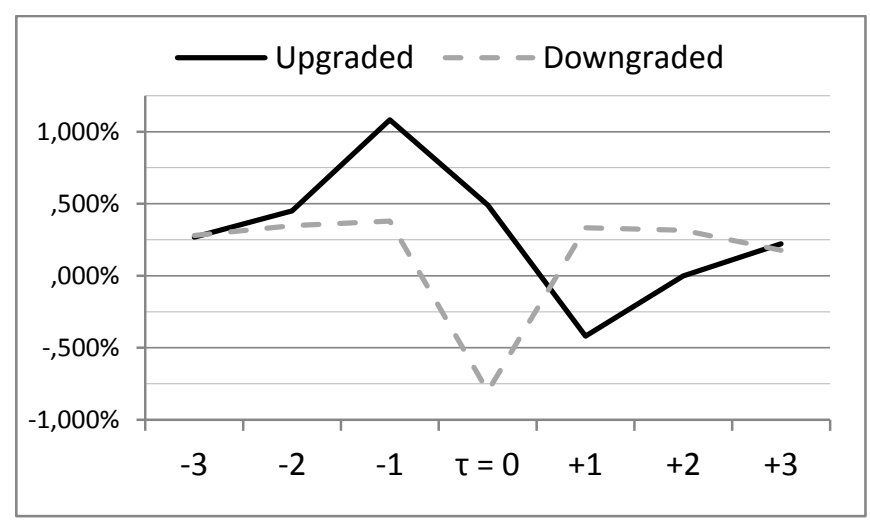

These results show that as a consequence to the publishing of reputation rankings, investors significantly changed their willingness to buy, which is indicated by rising or falling share prices around the announcement. However, not all effects are significant, which emphasizes the importance of the event window specification. But the impact at the event day is proven without a doubt.

To make the results more comparable to the study of Fornell et al. (2006), some portfolio studies are conducted. The portfolios are created at the event day $(\tau=0)$ and kept stable until the next publication. Every portfolio contains the selected upand downgraded companies of the rankings as tested before. The cumulative portfolio returns are plotted against the index $\left(\mathrm{CDAX}^{\circledR}\right)^{9}$ below. We have deliberately not adopted the aggregated presentation of Fornell et al. (2006) because of two reasons. On the one hand, the results are more detailed and hence the effects do not overlap. On the other hand, the rankings which we used were only publicized in a two year cycle. In contrast to Fornell et al. (2006), the downgraded companies are presented as well.

\footnotetext{
${ }^{9}$ See Chapter 4
} 
Figure 6: Cumulative returns, selected companies ranked in 2000

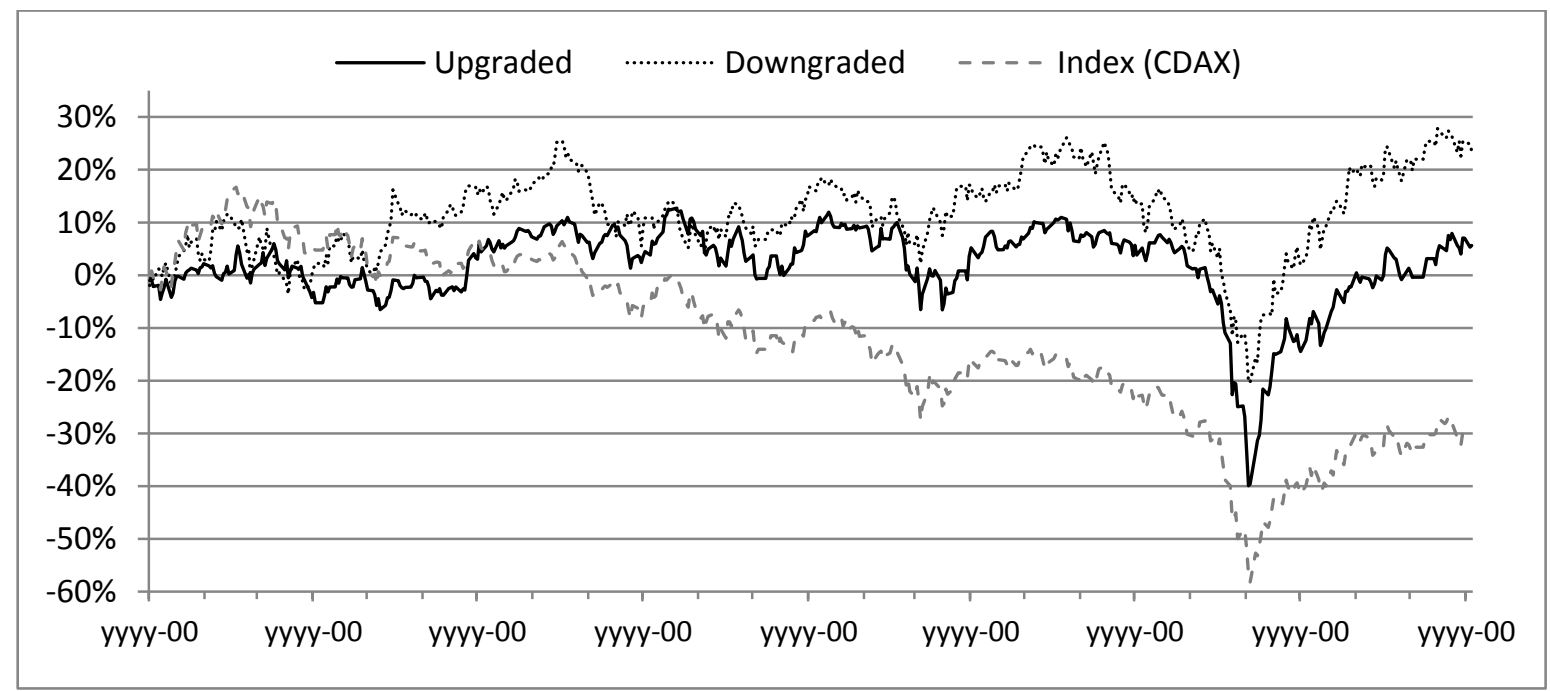

Figure 7: Cumulative returns, selected companies ranked in 2002

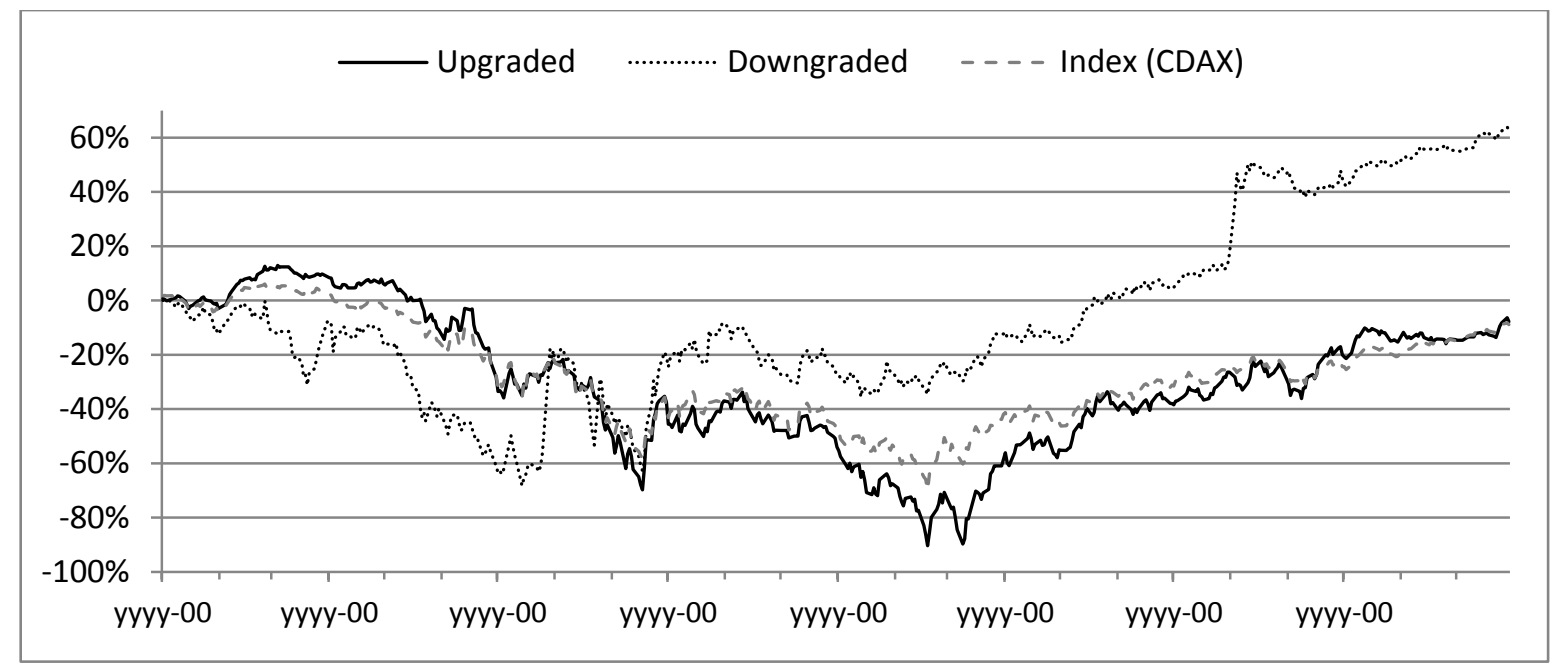

Figure 8: Cumulative returns, selected companies ranked in 2004

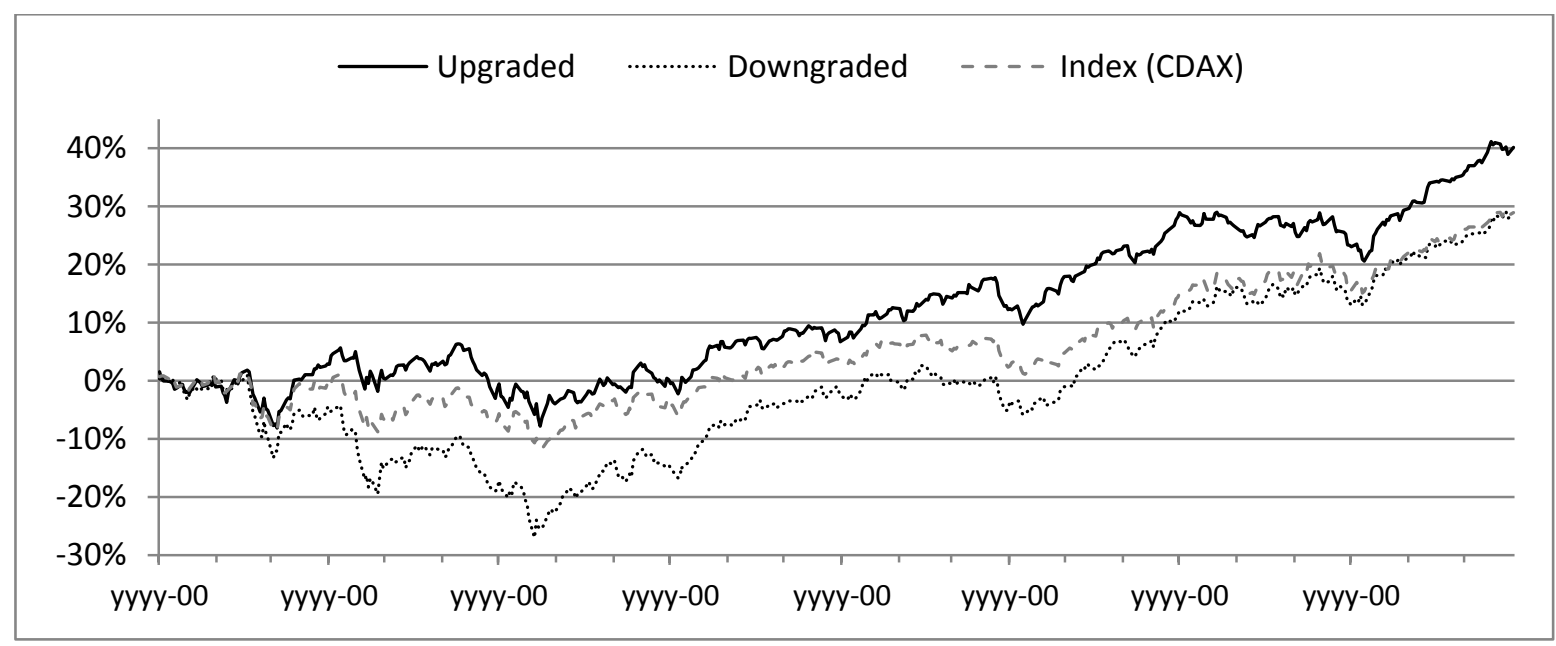


Figure 9: Cumulative returns, selected companies ranked in 2006

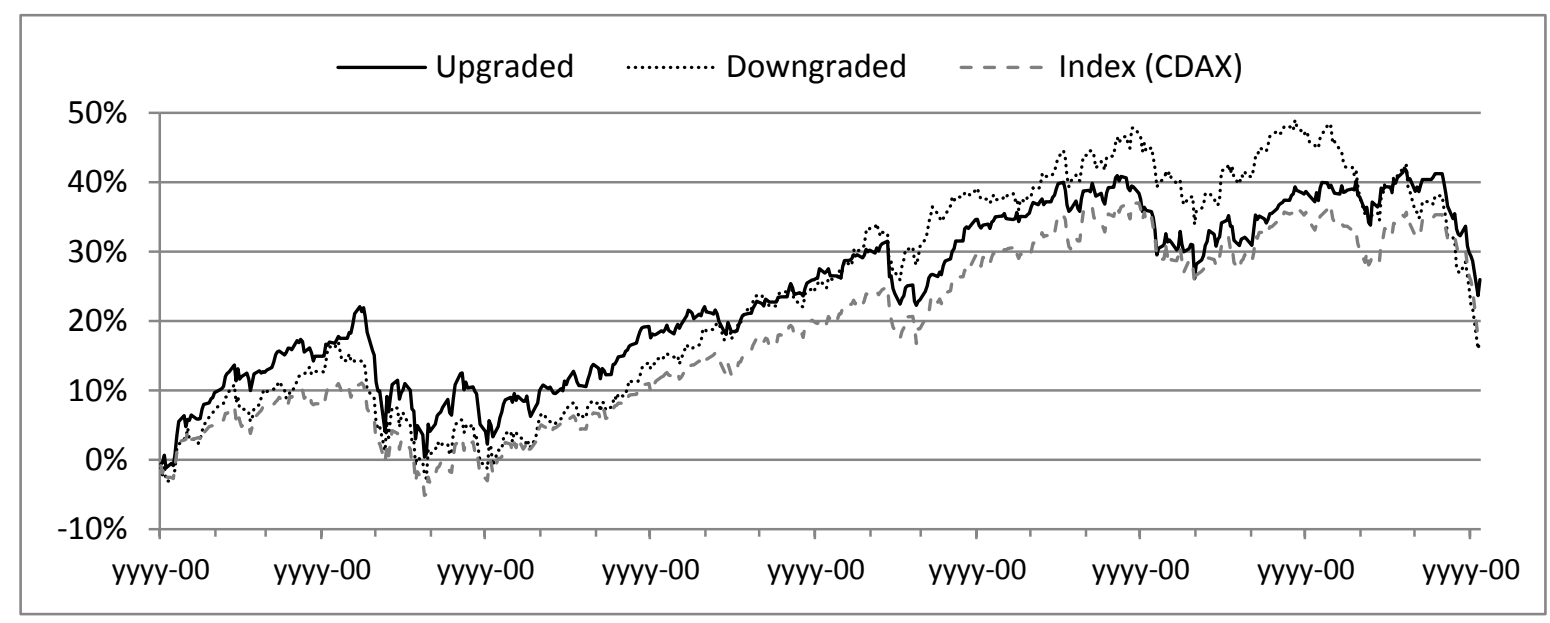

Figure 10: Cumulative returns, selected companies ranked in 2008

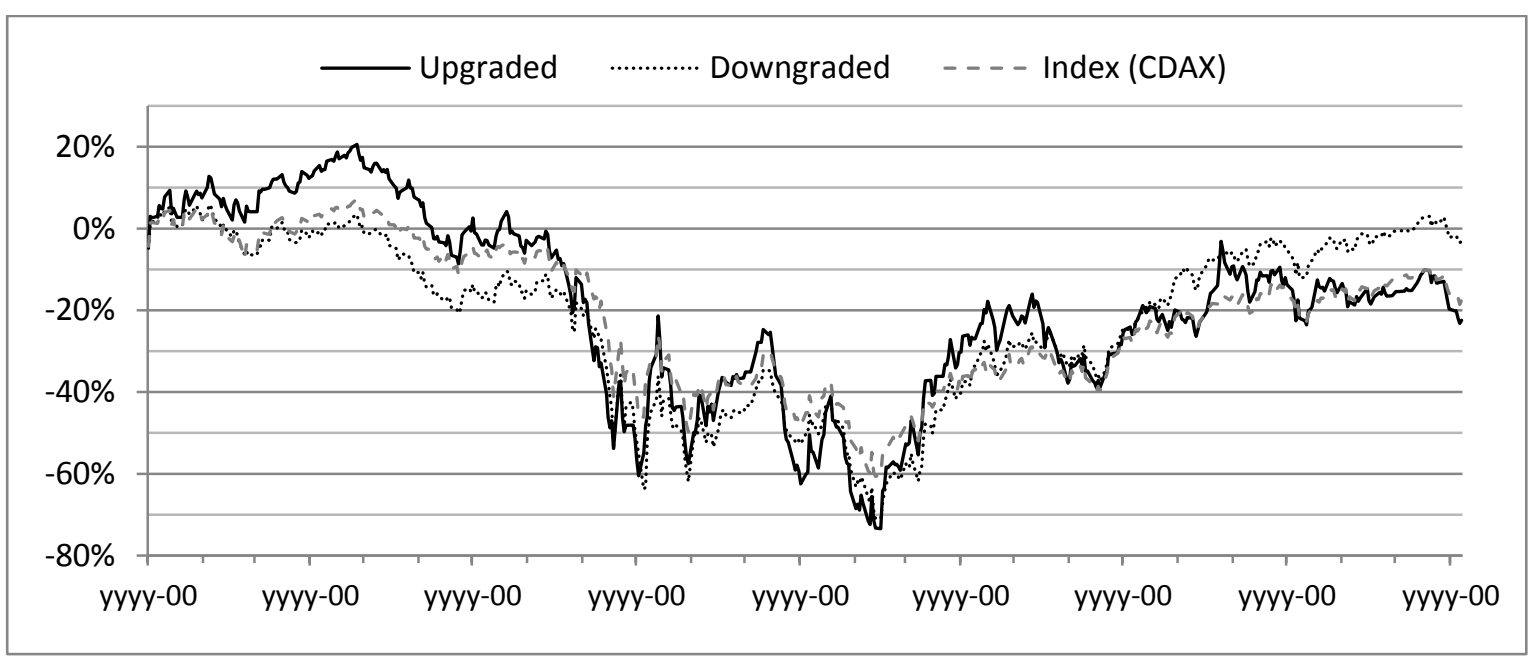

These diagrams illustrate two things. First, the final cumulated portfolio return depends on the date of portfolio creation. Second, the influence of corporate reputation on share prices is overlapped by other factors in the long run.

\section{Discussion}

The present analysis demonstrates two distinct things based on the used data. On the one hand, publications of reputation rankings have an impact on shareholder value. We find, as expected, a positive announcement effect if the relative ranking position had been significantly improved and a negative effect if the relative position had been deteriorated in comparison to the competitors.

On the other hand, neither good or bad reputation scores in a ranking, nor their changes are solely appropriate to generate excess returns in the long run. 
Both results are in line with our earlier argumentation. The announcement effect clearly indicates that corporate reputation is information which is not public. As a consequence, corporate reputation has to be disclosed. However, once published, the information are quick "fully" reflected in share prices. Therefore, we could show that the announcement effect is significant at the day of publication and limited to a small event window. This confirms the assumed market efficiency and the resulting specification of the short event windows.

Furthermore, the assumption of efficient capital markets is also supported by the results of our portfolio studies. As we have shown, the information is dominated by other factors in the long run. Consequently, it is impossible to generate excess returns based on these reputation signals in the long run.

However, our findings contradict the empirical results of previous studies of Hannon and Milkovich (1996), Ittner and Larcker (1998), Anderson and Smith (2006), Fornell et al. (2006) and Abraham et al. (2008). In order to clarify the underlying causes for these contradictions we take a closer look at the similarities and differences between data and methodologies in the following.

When hunting for announcement effects of published reputation rankings, Hannon and Milkovich (1996) use the disclosure of six different American human resource rankings; Fornell et al. (2006) use the American Customer Satisfaction Index (ACSI) data and Abraham et al. (2008) use the publication of the Reputation Quotient (RQ, see Fombrun et al., 2000) ${ }^{10}$. All these American rankings had been published in the "popular business press" (Hannon \& Milkovich, 1996) and to some extend via internet additionally. This publication process corresponds to the process of the rankings we used except for the market under consideration.

Apart from Hannon and Milkovich's study which analysed the publication of rankings between 1982 to 1989, the periods of interest of Fornell et al. (2006), 1999 to 2002, Abraham et al. (2008), 2001-2005, do overlap with our data. However, there are considerable differences in the ranking publication cycles. Solely, the ranking Most Preferred used by Hannon and Molkovich (1996) had been published in a two-year cycle like the ranking of the Manager Magazin we used. In contrast, the ACSI data used by Fornell et al. (2006) have been published quarterly, the RQ (Abraham et al.,

\footnotetext{
${ }^{10}$ We excluded the study of Ittner and Larcker (1998) in the discussion due to the fact that Fornell et al. (2006) used publications of the same ranking. Fornell et al. (2006) analysed just more recent announcements and had overcome, in our view, some methodological weaknesses.
} 
2008) and Best for Working Mothers (Hannon \& Milkovich, 1996) data have been published yearly. Additional rankings which are investigated by Hannon and Milkovich (1996) had been published just once (100 Best to Work for - 1984; Best for Women - 1988 \& Best for Black Engineers - 1989) or twice (Best for Blacks - 1982 \& 1986) during the period of interest.

Due to the fact that various event dates are sufficient respectively necessary for an event study to minimize external effects (Binder, 1985), the statistical power and informative value of the results is reduced to a large extend regarding the three rankings published just once.

In principle, despite various research questions and respondents, all rankings which are used in the studies have the potential to cause announcement effects due to the disclosure of non-public information as explained earlier. Only, regarding the quarterly announcements of ACSI data, one could suppose that the effects tend to be very small. This would be attributable to the short time span between two announcements. Thus, it is less likely that the expectations of investors differ widely to change the buying intentions.

In order to test for announcement effects we used the same methodology - an event study - as Hannon and Milkovich (1996), Fornell et al. (2006) and Abraham et al. (2008) have done. Nevertheless, there are considerable methodical differences between the studies which could lead to diverging results. From our point of view, the most important difference is how events are defined in the respective studies. These definitions are crucial to select and group the companies.

Hannon and Milkovich (1996) defined the event as publication of a human resource ranking. Consequently, all companies which are listed in the ranking and publically tradable were grouped and tested. Contrary to this, Abraham et al. (2008) defined the event as listed in a specific quartile if the $R Q$ are published. This definition takes into account the relative position of a company in comparison to the competitors. Therefore, the companies are grouped in correspondence to its quartiles and tested over all rankings. In our opinion, the problem of both event definitions is that they neglect the necessity of a changed (relative or absolute) position of companies. Without any change, there is no need for investors to revalue share prices. In line with this argument, Fornell et al. (2006) defined the event as the publication of a changed ACSI scores. That means they studied the impact of changed reputation scores in a ranking like we do. However, Fornell et al. (2006) have considered just an 
absolute change of scores what is not a sufficient indicator, in our view, for an improved or declined competitive position. Consequently, we choose a dynamic perspective which considers the relative changes in the reputation measure in comparison to both the previous ranking and the overall mean.

A comparison of the event window definitions shows that all studies used primarily the period of publication $(\tau=0)$ and some additional event windows of maximum 5 units of time ( $\tau=-2$ to $\tau=2$ ). Only Abraham et al. (2008) were gone beyond that and used an additional window of 250 days to make their results more comparable to the study of Anderson and Smith (2006). The criticism towards such a long event window and, accordingly, towards Anderson and Smith's study (2006) is the same (see McWilliams \& Siegel, 1997) which has led us to limit our event windows to a maximum of 3 days.

The estimation windows of all analyses are differently defined as well in length, of 12 respectively 6 months (Hannon \& Milkovich, 1996), of 255 trading days (Fornell et al., 2006) and 100 trading days (Abraham et al., 2008) as in its position in time. For example, Fornell et al. (2006) used a gap between estimation and event window of 46 days. Whereas Abraham et al. (2008) used a gap of 100 trading days to ensure that the estimated parameters are not influenced by the event itself. Even if it is common practice to use such a gap, its completely arbitrary definition offers an opportunity to influence the results. This potential effect is partially visible if one compares the excess returns of our results and the additional provided control window ( $\tau=-3$ to $\tau=3$ ) at $\tau=0(0.383$ compared to 0.490$)$. To avoid such effects we consciously renounce for any gap. With regard to the various lengths of estimation windows, we are of the opinion that the impact can be neglected as long as the period is long $(\tau \geq 100)$.

Furthermore, variations of calculating actual ex-post returns could be another potential cause for diverging results. Hannon and Milkovich (1996) and Fornell et al. (2006) used discrete returns. In contrast to, Abraham et al. (2008) used log transformed returns as we do. However, based on the choice of Hannon and Milkovich (1996) to use monthly returns, one could fundamentally question if those returns are appropriate to test for announcement effects. Finally, it is almost impossible to isolate an effect due to the event in such aggregated data.

Besides the event definition, another very important factor is the selection of a market model. But, all studies, including this one, used the classical CAPM as market model. 
However, in opposition to Hannon and Milkovich (1996) and Fornell et al. (2006) who have estimated the parameter $\alpha$ as intercept, which corresponds to $R_{f, \tau}$ in our model (see equation 8), Abraham et al. (2008) have set $\alpha$ to be zero. The $\beta$ parameter, as a risk measure in comparison to the market, is estimated in all studies except the study of Abraham et al. (2008). Abraham et al. (2008) set $\beta$ to be 1, which implies that all companies are equally risky and risky as the entire market. That is not in line with finance theory.

To put it in a nutshell, we believe that not the various used rankings but rather methodological differences are attributable to the absence of event studies which could validate announcement effects when reputation rankings are published. Nevertheless, in order to show an effect resulting from corporate reputation, the data should fulfill some basic criteria. According to Bromley (2002a) data should not be colluded due to sector membership of respondents and not be biased by financially focused criteria. In conformity with Schwaiger (2004), both criteria are fulfilled by Manager Magazin data. This also holds true for ACSI data used by Fornell et al. (2006) and all reputation rankings used by Hannon and Milkovich (1996). The suitability of $R Q$ data (Abraham et al., 2008) can be questioned (Schwaiger, 2004), whereas the Fortune data used by Anderson and Smith (2006) are inappropriate with respect to these criteria (Bromley, 2002a).

\section{Limitations and further research}

Our study is limited to some extent. With regard to the underlying methodology, we have strong assumptions about the capital market and its information efficiency. In addition, as criticized by Bromley (2002a), our results are restricted to publicly traded companies.

Furthermore, there are limitations with respect to the data. On the one hand, we are restricted to available data. On the other hand, a selection bias might exist induced by the choice of respondents. But following our line of argument including the assumptions, the used stakeholder group should be suitable to provide the information for "all" stakeholders. Consequently, the arguments that managers and directors are overrepresented (Bromley, 2002a) and revealing just incidental knowledge about stakeholders due to the influence of corporate communications 
(Schwaiger, Raithel \& Schloderer, 2009), can be neglected. All stakeholders are influenced by corporate communication.

Therefore, in order to clarify the general presence of announcement effects by publishing reputation rankings, additional research needs to be conducted but with different data. Moreover, in future research, the relative character (in comparison to the competitors) of the reputation construct should be considered, as well as that events have to trigger a revaluation of share prices. For this purpose, it is appropriate to adopt our methodological design.

\section{Appendix}

List of variables

\begin{tabular}{|ll|ll|}
\hline$S V$ & Shareholder value & $C F$ & Cash flow \\
$r$ & return & $\tau$ & Time index \\
$i$ & Company index & $r_{i, \tau}$ & Discrete return of company $i$ at time $\tau$ \\
$P_{i, \tau}$ & Price of company $i$ at time $\tau$ & $R_{i, \tau}$ & Return of company $i$ at time $\tau$ \\
$R_{f, \tau}$ & Secure (fix) return at time $\tau$ & $R_{m, \tau}$ & Market return at time $\tau$ \\
$A R$ & Abnormal return & $\overline{A R}$ & averaged abnormal return \\
$\overline{C A R}$ & $\begin{array}{l}\text { Cumulative averaged abnormal } \\
\text { return }\end{array}$ & $N\left(\mu_{i}, \sigma_{i}^{2}\right)$ & $\begin{array}{l}\text { Normal distribution with expected } \\
\text { value } \mu \text { and variance } \sigma\end{array}$ \\
$\varepsilon_{i}$ & Error term of company $i$ & $\beta_{i}$ & Estimated parameter of company $i$ \\
$n$ & Number of companies & & \\
\hline
\end{tabular}

Lists of up- and downgraded companies and their corresponding changes (differences of the relative positions in comparison to the previous year) which are contained in the final sample

\begin{tabular}{|l|lr|lr|lr|}
\cline { 2 - 7 } \multicolumn{1}{l|}{} & Upgraded & \multicolumn{4}{l|}{} \\
\hline 2000 & Allianz & $4,2 \%$ & Deutsche Bank & $6,8 \%$ & Linde & $4,9 \%$ \\
& MG Technologies & $6,8 \%$ & Münchener Rück & $4,0 \%$ & Porsche & $4,8 \%$ \\
& SAP & $5,1 \%$ & & & & \\
& BMW & $4,1 \%$ & Deutsche Post & $16,4 \%$ & Bayer. Hypo- \& & $7,2 \%$ \\
& Münchener Rück & $4,8 \%$ & Stinnes & $6,5 \%$ & & \\
\hline
\end{tabular}




\begin{tabular}{|l|lr|lr|lr|}
\hline 2004 & Adidas & $4,8 \%$ & Bayer & $5,4 \%$ & Beiersdorf & $4,8 \%$ \\
& Henkel & $5,0 \%$ & Puma & $16,8 \%$ & TUI & $5,9 \%$ \\
& United Internet & $6,8 \%$ & & & & \\
\hline 2006 & Adidas & $4,3 \%$ & Deutsche Post & $7,1 \%$ & Deutsche Telekom & $4,4 \%$ \\
& Fraport & $5,2 \%$ & Gea Group & $5,2 \%$ & Heidelberger & $13,0 \%$ \\
& & & & Cement & \\
& MAN & $4,6 \%$ & Mobilcom & $10,8 \%$ & Münchener Rück & $4,3 \%$ \\
& Puma & $5,3 \%$ & United Internet & $5,6 \%$ & & \\
& Arcandor & $7,4 \%$ & Commerzbank & $7,8 \%$ & Daimler & $5,0 \%$ \\
& Deutsche Bank & $4,1 \%$ & Gea Group & $5,7 \%$ & Bilfinger Berger & $5,3 \%$ \\
& Heidelberger Druck & $10,9 \%$ & Hochtief & $7,9 \%$ & Linde & $5,3 \%$ \\
& Thyssen Krupp & $4,4 \%$ & Volkswagen & $9,0 \%$ & & \\
\hline
\end{tabular}

\begin{tabular}{|c|c|c|c|c|c|c|}
\hline \multirow[b]{2}{*}{2000} & \multicolumn{6}{|l|}{ Downgraded } \\
\hline & Hoechst & $-6,2 \%$ & Siemens & $-4,6 \%$ & & \\
\hline \multirow[t]{4}{*}{2002} & BASF & $-5,1 \%$ & Bayer & $-11,7 \%$ & Commerzbank & $-4,6 \%$ \\
\hline & Daimler & $-5,4 \%$ & Deutsche Bank & $-6,4 \%$ & Deutsche Telekom & $-10,9 \%$ \\
\hline & Philipp Holzmann & $-26,0 \%$ & Mobilcom & $-11,9 \%$ & SAP & \\
\hline & Sixt & $-6,7 \%$ & & & & \\
\hline \multirow[t]{4}{*}{2004} & Allianz & $-5,4 \%$ & Commerzbank & $-10,7 \%$ & Deutsche Bank & $-12,9 \%$ \\
\hline & Deutsche Post & $-7,0 \%$ & Deutsche Telekom & $-4,4 \%$ & Heidelberger Druck & $-8,4 \%$ \\
\hline & Heidelberger Cement & $-7,3 \%$ & $\begin{array}{l}\text { Bayer. Hypo- \& } \\
\text { Vereinsbank }\end{array}$ & $-14,1 \%$ & MLP & $-11,2 \%$ \\
\hline & Mobilcom & $-13,8 \%$ & Münchener Rück & $-8,4 \%$ & Volkswagen & $-4,7 \%$ \\
\hline \multirow[t]{3}{*}{2006} & Arcandor & $-28,3 \%$ & Daimler & $-20,5 \%$ & EON & $-12,9 \%$ \\
\hline & Heidelberger Druck & $-4,4 \%$ & Infineon & $-5,1 \%$ & RWE & $-12,5 \%$ \\
\hline & Siemens & $-8,5 \%$ & Volkswagen & $-17,9 \%$ & & \\
\hline \multirow[t]{5}{*}{2008} & Allianz & $-7,0 \%$ & BASF & $-4,2 \%$ & BMW & $-5,0 \%$ \\
\hline & Deutsche Post & $-4,4 \%$ & Deutsche Telekom & $-15,6 \%$ & EON & $-9,3 \%$ \\
\hline & $\begin{array}{l}\text { Fresenius Medical } \\
\text { Care }\end{array}$ & $-5,1 \%$ & Metro & $-4,4 \%$ & $\begin{array}{l}\text { ProSiebenSat.1 } \\
\text { Media }\end{array}$ & $-5,2 \%$ \\
\hline & MTU Aero Engines & $-4,8 \%$ & Porsche & $-4,8 \%$ & Puma & $-6,7 \%$ \\
\hline & RWE & $-7,4 \%$ & Siemens & $-12,7 \%$ & TUI & $-5,2 \%$ \\
\hline
\end{tabular}




\section{References}

Aaker, D. A. (1991). Managing Brand Equity: Capitalizing on the Value of a Brand Name. Free Press, New York, NY.

Abimbola, T. \& Vallaster, C. (2007). Brand, organisational identity and reputation in SMEs: an overview. Qualitative Market Research, 10 (4), 341-348.

Abraham, S. E., Friedman, B. A., Khan, R. H. \& Skolnik, R. J. (2008). Is publication of the Reputation Quotient (RQ) sufficient to move stock prices. Corporate Reputation Review, 11 (4), 308319.

Aharony, J. \& Swary, I. (1980). Quarterly dividend and earnings announcements and stockholders' returns: an empirical analysis. The Journal of Finance, 35 (1), 1-12.

Anderson, J. \& Smith, G. (2006). A great company can be a great investment. Financial Analysts Journal, 62 (4), 86-93.

Barclay, M. J. \& Litzenberger, R. H. (1988). Announcement effects of new equity issues and the use of intraday price data. Journal of Financial Economics, 21 (1), 71-99.

Barnett, M. L., Jermier, J. M. \& Lafferty, B. A. (2006). Corporate reputation: the definitional landscape. Corporate Reputation Review, 9 (1), 26-38.

Barney, J. (1991). Firm resources and sustainable competitive advantage. Journal of Management, 17 (1), 99-120.

Beatty, R. P. \& Ritter, J. R. (1986). Investment banking, reputation, and the underpricing of initial public offerings. Journal of Financial Economics, 15 (1-2), 213-232.

Bernard, V. L. \& Thomas, J. K. (1989). Post-earnings-announcement drift: delayed price response or risk premium. Journal of Accounting Research, 27, 1-36.

Binder, J. J. (1985). Measuring the effects of regulation with stock price data. Rand Journal of Economics, 16 (2), 167-183.

Boot, A. W. A., Greenbaum, S. I. \& Thakor, A. V. (1993). Reputation and discretion in financial contracting. American Economic Review, December, 1165-1183.

Boulstridge, E. \& Carrigan, M. (2000). Do consumers really care about corporate responsibility? Highlighting the attitude-behaviour gap. Journal of Communication Management, 4 (4), 355368.

Bromley, D. B. (2002a). Comparing corporate reputation: league tables, quotients, benchmarks, or case studies? Corporate Reputation Review, 5 (1), 35-50.

Bromley, D. B. (2002b). An examination of issues that complicate the concept of reputation in business studies. International Studies of Management and Organization, 32 (3), 65-81.

Brown, B. \& Perry, S. (1994). Removing the financial performance halo from Fortune's 'Most Admired' companies. Academy of Management Journal, 37, 1347-1359.

Caminiti, S. (1992). The payoff from a good reputation. Fortune, 125 (3), 49-53.

Carter, S.M. \& Deephouse, D. L. (1999), Tough talk and soothing speech: managing reputations for being tough and for being good. Corporate Reputation Review, 2 (4), 308-332. 
Caruana, A. (1997). Corporate reputation: concept and measurement. Journal of Product \& Brand Management, 6 (2), 109-118.

Chun, R. (2005). Corporate reputation: meaning and measurement. International Journal of Management Reviews, 7 (2), 91-109.

Chun, R. \& Davies, G. (2006). The influence of corporate character on customers and employees. The Academy of Marketing Science, 34 (2), 138-145.

Cooper, M. J., Dimitrov, O. \& Rau, P. R. (2001). A Rose.com by any other name. Journal of Finance, $56(6), 2371-2388$.

Cornell, B. \& Landsman, W. R. (1989). Security price response to quarterly earnings announcements and analysts' forecast revisions. The Accounting Review, 64 (4), 680-692.

Davies, G. \& Miles, L. (1998). Reputation management: theory versus practice. Corporate Reputation Review, 2 (1), 16-27.

Davies, G. \& Chun, R. (2002). Gaps between the internal and external perceptions of corporate brand. Corporate Reputation Review, 5 (2/3), 144-158.

Deephouse, D. L. (2000). Media reputation as a strategic resource: an integration of mass communication and resource-based theories. Journal of Management, 26 (6), 1091-1112.

Dhir, K. S. \& Vinen, D. (2005). Managing corporate respectability. Corporate Communications: An International Journal, 10 (1), 5-23.

Dierickx, I. \& Cool, K. (1989). Asset stock accumulation and sustainable competitive advantage. Management Science, 35, 1504-1511.

Dowling, G. R. (1986). Managing your corporate images. Industrial Marketing Management, 15 (2), 109-115.

Dowling, G. (2006). How good corporate reputations create corporate value. Corporate Reputation Review, 9 (2), 134-143.

Dunbar, R. L. M. \& Schwalbach, J. (2000). Corporate reputation and performance in Germany. Corporate Reputation Review, 4 (1), $42-49$.

Eberl, M. \& Schwaiger, M. (2005). Corporate reputation: disentangling the effects on financial performance. European Journal of Marketing, 39 (7/8), 839-854.

Eidson, C. \& Master, M. (2000). Top ten ... most admired ... most respected: who makes the call. Across the Board, 37 (3), 16-22.

Fama, E. F. (1970). Efficient capital markets: a review of theory and empirical work. The Journal of Finance, 25 (2), 383-417.

Fama, E. F. (1991). Efficient capital markets: II. The Journal of Finance, 46 (5), 1575-1617.

Fombrun, C. J. (1996). Reputation: realizing value from the corporate image. Harvard Business School Press.

Fombrun, C. J. \& Shanley, M. (1990). What's in a name? Reputation building and corporate strategy. Academy of Management Journal, 33 (2), 233-258. 
Fombrun, C. J., Gardberg, N. \& Sever, J. (2000). The reputation quotient: a multi-stakeholder measure of corporate reputation. Journal of Brand Management, 7 (4), 241-255.

Fornell, C., Mithas, S., Morgeson III, F. V. \& Krishnan, M. S. (2006). Customer satisfaction and stock prices: high returns, low risk. Journal of Marketing, 70, 3-14.

Freiesleben, J. (2006). What are quality reputations worth. Quality Progress, 39 (2), 35-41.

Goldberg, M. E. \& Hartwick, J. (1990). The effects of advertiser reputation and extremity of advertising claim on advertising effectiveness. Journal of Consumer Research, 17 (2), 172-179.

Grewal, D., Krishnan, R., Baker, J. \& Borin, N. (1998). The effect of store name, brand name and price discounts on consumers' evaluations and purchase intentions. Journal of Retailing, 74 (3), 331-352.

Groenland, E. A. G. (2002). Qualitative research to validate the RQ-dimensions. Corporate Reputation Review, 4 (4), 308-315.

Grullon, G. \& Michaely, R. (2004). The information content of share repurchase programs. The Journal of Finance, 59 (2), 651-680.

Hall, R. (1992). The strategic analysis of intangible resources. Strategic Management Journal, 13 (2), 135-144.

Hallowell, R. (1996). The relationships of customer satisfaction, customer loyalty, and profitability: an empirical study. International Journal of Service Industry Management, 7, 27-42.

Hannon, J. M. \& Milkovich, G. T. (1996). The effect of human resource reputation signals on share prices: an event study. Human Resource Management, 35 (3), 405-424.

Hunt, S.D. \& Morgan, R. M. (1995). The comparative advantage theory of competition. Journal of Marketing, 59 (2), 1-15.

Ittner, C. D. \& Larcker, D. F. (2003). Are nonfinancial measures leading indicators of financial performance? An analysis of customer satisfaction. Journal of Accounting Research, 36, 135.

Ittner, C. D. \& Larcker, D. F. (2003). Coming up short on nonfinancial performance measurement. Harvard Business Review, November, 88-95.

Inglis, R., Morley, C. \& Sammut, P. (2006). Corporate reputation and organisational performance: an Australian study. Managerial Auditing Journal, 21 (9), 934-947.

Jones, G. H., Jones, B. H., \& Little, P. (2000). Reputation as reservoir: buffering against loss in times of economic crisis. Corporate Reputation Review, 3 (1), 21-29.

Kazoleas, D., Kim, Y. \& Moffitt, M. A. (2001). Institutional image: a case study. Corporate Communications: An International Journal, 6 (4), 205-216.

Klein, B. \& Leffler, K. B. (1981). The role of market forces in assuring contractual performance. Journal of Political Economy, 89 (4), 615-641

Kotha, S., Rajgopal, S. \& Rindova, V. (2001). Reputation building and performance: an empirical analysis of the Top-50 pure internet firms. European Management Journal, 19 (6), 571-586. 
Lafferty, B. A. \& Goldsmith, R. E. (1999). Corporate credibility's role in consumers' attitudes and purchase intentions when a high versus a low credibility endorser is used in the ad. Journal of Business Research, 44 (2), 109-116.

Landon, S. \& Smith, C. E. (1997). The use of quality and reputation indicators by consumers: the case of Bordeaux wine. Journal of Consumer Policy, 20, 289-323.

Landsman, W. R. \& Maydew, E. L. (2002). Has the information content of quarterly earnings announcements declined in the past three decades. Journal of Accounting Research, 40 (3), 797-808.

Lintner, J. (1965). Security prices, risk, and maximal gains from diversification. Journal of Finance, 20 (4), 587-615.

Little, P. L. \& Little, B. L. (2000). Do perceptions of corporate social responsibility contribute to explaining differences in corporate price-earnings ratios? A research note. Corporate Reputation Review, 3 (2), 137-142.

Lucey, B. M. \& Dowling, M. (2005). The role of feelings in investor decision-making. Journal of Economic Surveys, 19 (2), 211-237

MacKinlay, A. C. (1997). Event studies in economics and finance. Journal of Economic Literature, 35 (1), 13-39.

Masulis, R. W. (1980). The effects of capital structure change on security prices: a study of exchange offers. Journal of Financial Economics, 8, 139-177.

Masulis, R. W. (1983). The impact of capital structure change on firm value. Journal of Finance, 38, 107-126.

McGregor, D. G., Slovic, P., Dreman, D. \& Berry, M. (2000). Imagery, affect, and financial judgment. The Journal of Psychology and Financial Markets, 1, 104-110.

McGuire, J. B., Sundgren, A., \& Schneeweis, T. (1988). Corporate social responsibility and firm financial performance. Academy of Management Journal, 31 (4), 854-872.

McGuire, J. B., Schneeweis, T., \& Branch, B. (1990). Perceptions of firm quality: A cause or result of firm performance. Journal of Management, 16 (1), 167-180.

McWilliams, A. \& Siegel, D. (1997). Event studies in management research: theoretical and empirical issues. The Academy of Management Journal, 40 (3), 626-657.

Mossin, J. (1966). Equilibrium in a capital asset market. Econometrica, 34 (4), 768-783.

Nakra, P. (2000). Corporate reputation management: "CRM" with a strategic twist. Public Relations Quarterly, 45 (2), 35-42.

Nguyen, N. \& Leblanc, G. (2001). Corporate image and corporate reputation in customers' retention decisions in services. Journal of Retailing and Consumer Services, 8 (4), 227-236.

Orlitzky, M. \& Benjamin, J. D. (2001). Corporate social performance and firm risk: a meta-analytic review. Business and Society, 40 (4), 369-396.

Podolny, J. (1993). A status-based model of market competition. American Journal of Sociology, 98 (4), 829-872. 
Puncheva, P. (2008). The role of corporate reputation in the stakeholder decision-making process. Business \& Society, 47 (3), 272-290.

Preece, S., Fleisher, C. \& Toccacelli, J. (1995), Building a reputation along the value chain at Levi Strauss. Long Range Planning, 28 (6), 88-98.

Rappaport, A. (1998). Creating shareholder value - a guide for managers and investors. The Free Press, New York.

Rindova, V. P., Williamson, I. O., Petkova, A. P. \& Sever, J. M. (2005). Being good or being known: an empirical examination of the dimensions, antecedents, and consequences of organizational reputation. Academy of Management Journal, 48 (6), 1033-1049.

Roberts, P. W. \& Dowling, G. R. (2002). Corporate reputation and sustained superior financial performance. Strategic Management Journal, 23, 1077-1093.

Rogerson, W. P. (1983). Reputation and product quality. The Bell Journal of Economics, 14 (2), 508516.

Rose, C. \& Thomsen, S. (2004). The impact of corporate reputation on performance: some Danish evidence. European Management Journal, 22 (2), 201-210.

Sabate, J. M. \& Puente, E. Q. (2003). Empirical analysis of the relationship between corporate reputation and financial performance: a survey of the literature. Corporate Reputation Review, 6 (2), 161-178.

Sánchez, J. L. F. \& Satorrío, L. L. (2007). The creation of value through corporate reputation. Journal of Business Ethics, 76, 335-346.

Sawilowsky, S. S. (2002). Fermat, Schubert, Einstein, and Behrens-Fisher: The probable difference between two means when $\sigma_{1}^{2} \neq \sigma_{2}^{2}$. Journal of Modern Applied Statistical Methods, 1 (2), 461-472.

Schultz, M., Mouritsen, J. \& Gabrielsen, G. (2001). Sticky reputation: analyzing a ranking system. Corporate Reputation Review, 4 (1), 24-41.

Schwaiger, M. (2004). Components and parameters of corporate reputation - an empirical study. Schmalenbach Business Review, 56 (1), 46-71.

Schwaiger, M., Raithel, S. \& Schloderer, M. (2009). Recognition or rejection - how a company's reputation influences stakeholder behavior. Reputational Capital, 39-55.

Schwalbach, J. (2000). Image, Reputation und Unternehmenswert. Baerns, Barbara/Raupp, Juliana [eds.], Information und Kommunikation in Europa, Forschung und Praxis, Transnational Communication in Europe, Research and Practice, 287-297.

Seeger, H. (1998). Insiderhandel am deutschen Aktienmarkt: eine empirische Untersuchung von Existenz und Erkennbarkeit. Europäische Hochschulschriften, Reihe 5, Volks- und Betriebswirtschaft, Band 2303, Europäischer Verlag der Wissenschaften.

Selnes, F. (1993). An examination of the effect of product performance on brand reputation, satisfaction and loyalty. European Journal of Marketing, 27 (9), 19-36.

Seyhun, H. N. (1986). Insiders' profits, costs of trading, and market efficiency. Journal of Financial Economics, 16 (2), 189-212. 
Sharpe, W. F. (1964). Capital asset prices: a theory of market equilibrium under conditions of risk. Journal of Finance, 19 (3), 425-442.

Shapiro, C. (1983). Premiums for high quality products as returns to reputations. The Quarterly Journal of Economics, 98 (4), 659-680.

Shefrin, H. (2001). Do investors expect higher returns from safer stocks than from riskier stocks. The Journal of Psychology and Financial Markets, 2, 176-181.

Spence, M. (1974). Market-signaling. Harvard University Press, Cambridge

Srivastava, R. K., Mclnish, T. H., Wood, R. A. \& Capraro, A. J. (1997a). The value of corporate reputation: evidence from equity markets. Corporate Reputation Review, 1 (1/2), 61-68.

Srivastava, R. K., Shervani, T. A. \& Fahey, L. (1997b). Driving shareholder value: the role of marketing in reducing vulnerability and volatility of cash flows. Journal of Market Focused Management, 2, 49-64.

Srivastava, R. K., Shervani, T. A. \& Fahey, L. (1998). Market-based assets and shareholder value: a framework for analysis. Journal of Marketing, 62 (1), 2-18.

Stephens, C. P. \& Weisbach, M. S. (1998). Actual share reacquisitions in open-market repurchase programs. The Journal of Finance, 53 (1), 313-333.

Turban, D. B. \& Greening, D. W. (1997). Corporate social performance and organizational attractiveness to prospective employees. Academy of Management Journal , 40, 658-672.

Turban, D. B. \& Cable, D. M. (2003). Firm reputation and applicant pool characteristics. Journal of Organizational Behavior, 24 (6), 733-752.

Vergin, R. C. \& Qoronfleh, M. W. (1998). Corporate reputation and the stock market. Business Horizons, 41, 19-26.

Walker, K. (2010). A systematic review of the corporate reputation literature: definition, measurement, and theory. Corporate Reputation Review, 12 (4), 357-387.

Wartick, S. L. (1992). The relationship between intense media exposure and change in corporate reputation. Business \& Society, 31 (1), 33-49.

Wartick, S. L. (2002). Measuring corporate reputation: definition and data. Business and Society, 41 (4), 371-392.

Welch, B. L. (1937). The significance of the difference between two means when the population variances are unequal. Biometrika, 29, 350-362.

Williamson, O. E. (1985). The economic institutions of capitalism: firms, markets, relational contracting, The Free Press, New York.

Winkleman, M. (1999). The right stuff: survey on corporate reputation. Chief Executive, 143, 80-81.

Yoon, E., Guffey, H.G. \& Kijewski, V. (1993). The effects of information and company reputation on intentions to buy a business service. Journal of Business Research, 27, 215-228. 


\section{SFB 649 Discussion Paper Series 2011}

For a complete list of Discussion Papers published by the SFB 649, please visit http://sfb649.wiwi.hu-berlin.de.

001 "Localising temperature risk" by Wolfgang Karl Härdle, Brenda López Cabrera, Ostap Okhrin and Weining Wang, January 2011.

002 "A Confidence Corridor for Sparse Longitudinal Data Curves" by Shuzhuan Zheng, Lijian Yang and Wolfgang Karl Härdle, January 2011.

003 "Mean Volatility Regressions" by Lu Lin, Feng Li, Lixing Zhu and Wolfgang Karl Härdle, January 2011.

004 "A Confidence Corridor for Expectile Functions" by Esra Akdeniz Duran, Mengmeng Guo and Wolfgang Karl Härdle, January 2011.

005 "Local Quantile Regression" by Wolfgang Karl Härdle, Vladimir Spokoiny and Weining Wang, January 2011.

006 "Sticky Information and Determinacy" by Alexander Meyer-Gohde, January 2011.

007 "Mean-Variance Cointegration and the Expectations Hypothesis" by Till Strohsal and Enzo Weber, February 2011.

008 "Monetary Policy, Trend Inflation and Inflation Persistence" by Fang Yao, February 2011.

009 "Exclusion in the All-Pay Auction: An Experimental Investigation" by Dietmar Fehr and Julia Schmid, February 2011.

010 "Unwillingness to Pay for Privacy: A Field Experiment" by Alastair R. Beresford, Dorothea Kübler and Sören Preibusch, February 2011.

011 "Human Capital Formation on Skill-Specific Labor Markets" by Runli Xie, February 2011.

012 "A strategic mediator who is biased into the same direction as the expert can improve information transmission" by Lydia Mechtenberg and Johannes Münster, March 2011.

013 "Spatial Risk Premium on Weather Derivatives and Hedging Weather Exposure in Electricity" by Wolfgang Karl Härdle and Maria Osipenko, March 2011.

014 "Difference based Ridge and Liu type Estimators in Semiparametric Regression Models" by Esra Akdeniz Duran, Wolfgang Karl Härdle and Maria Osipenko, March 2011.

015 "Short-Term Herding of Institutional Traders: New Evidence from the German Stock Market" by Stephanie Kremer and Dieter Nautz, March 2011.

016 "Oracally Efficient Two-Step Estimation of Generalized Additive Model" by Rong Liu, Lijian Yang and Wolfgang Karl Härdle, March 2011.

017 "The Law of Attraction: Bilateral Search and Horizontal Heterogeneity" by Dirk Hofmann and Salmai Qari, March 2011.

018 "Can crop yield risk be globally diversified?" by Xiaoliang Liu, Wei Xu and Martin Odening, March 2011.

019 "What Drives the Relationship Between Inflation and Price Dispersion? Market Power vs. Price Rigidity" by Sascha Becker, March 2011.

020 "How Computational Statistics Became the Backbone of Modern Data Science" by James E. Gentle, Wolfgang Härdle and Yuichi Mori, May 2011.

021 "Customer Reactions in Out-of-Stock Situations - Do promotion-induced phantom positions alleviate the similarity substitution hypothesis?" by Jana Luisa Diels and Nicole Wiebach, May 2011.

\section{SFB 649, Spandauer Str. 1, D-10178 Berlin http:/ / sfb649.wiwi.hu-berlin.de}

This research was supported by the Deutsche Forschungsgemeinschaft through the SFB 649 "Economic Risk".

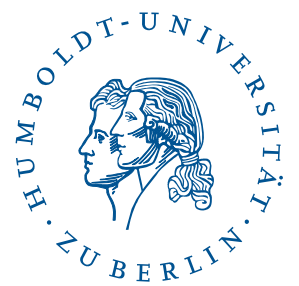




\section{SFB 649 Discussion Paper Series 2011}

For a complete list of Discussion Papers published by the SFB 649, please visit http://sfb649.wiwi.hu-berlin.de.

022 "Extreme value models in a conditional duration intensity framework" by Rodrigo Herrera and Bernhard Schipp, May 2011.

023 "Forecasting Corporate Distress in the Asian and Pacific Region" by Russ Moro, Wolfgang Härdle, Saeideh Aliakbari and Linda Hoffmann, May 2011.

024 "Identifying the Effect of Temporal Work Flexibility on Parental Time with Children" by Juliane Scheffel, May 2011.

025 "How do Unusual Working Schedules Affect Social Life?" by Juliane Scheffel, May 2011.

026 "Compensation of Unusual Working Schedules" by Juliane Scheffel, May 2011.

027 "Estimation of the characteristics of a Lévy process observed at arbitrary frequency" by Johanna Kappus and Markus Reiß, May 2011.

028 "Asymptotic equivalence and sufficiency for volatility estimation under microstructure noise" by Markus Reiß, May 2011.

029 "Pointwise adaptive estimation for quantile regression" by Markus Reiß, Yves Rozenholc and Charles A. Cuenod, May 2011.

030 "Developing web-based tools for the teaching of statistics: Our Wikis and the German Wikipedia" by Sigbert Klinke, May 2011.

031 "What Explains the German Labor Market Miracle in the Great Recession?" by Michael C. Burda and Jennifer Hunt, June 2011.

032 "The information content of central bank interest rate projections: Evidence from New Zealand" by Gunda-Alexandra Detmers and Dieter Nautz, June 2011.

033 "Asymptotics of Asynchronicity" by Markus Bibinger, June 2011.

034 "An estimator for the quadratic covariation of asynchronously observed Itô processes with noise: Asymptotic distribution theory" by Markus Bibinger, June 2011.

035 "The economics of TARGET2 balances" by Ulrich Bindseil and Philipp Johann König, June 2011.

036 "An Indicator for National Systems of Innovation - Methodology and Application to 17 Industrialized Countries" by Heike Belitz, Marius Clemens, Christian von Hirschhausen, Jens Schmidt-Ehmcke, Axel Werwatz and Petra Zloczysti, June 2011.

037 "Neurobiology of value integration: When value impacts valuation" by Soyoung Q. Park, Thorsten Kahnt, Jörg Rieskamp and Hauke R. Heekeren, June 2011.

038 "The Neural Basis of Following Advice" by Guido Biele, Jörg Rieskamp, Lea K. Krugel and Hauke R. Heekeren, June 2011.

039 "The Persistence of "Bad" Precedents and the Need for Communication: A Coordination Experiment" by Dietmar Fehr, June 2011.

040 "News-driven Business Cycles in SVARs" by Patrick Bunk, July 2011.

041 "The Basel III framework for liquidity standards and monetary policy implementation" by Ulrich Bindseil and Jeroen Lamoot, July 2011.

042 "Pollution permits, Strategic Trading and Dynamic Technology Adoption" by Santiago Moreno-Bromberg and Luca Taschini, July 2011.

043 "CRRA Utility Maximization under Risk Constraints" by Santiago MorenoBromberg, Traian A. Pirvu and Anthony Réveillac, July 2011.

\section{SFB 649, Spandauer Str. 1, D-10178 Berlin http:/ / sfb649.wiwi.hu-berlin.de}

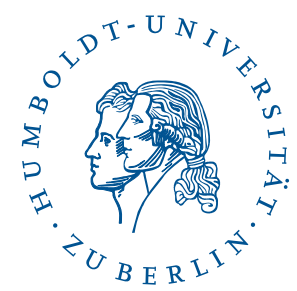




\section{SFB 649 Discussion Paper Series 2011}

For a complete list of Discussion Papers published by the SFB 649, please visit http://sfb649.wiwi.hu-berlin.de.

044 "Predicting Bid-Ask Spreads Using Long Memory Autoregressive Conditional Poisson Models" by Axel Groß-Klußmann and Nikolaus Hautsch, July 2011.

045 "Bayesian Networks and Sex-related Homicides" by Stephan Stahlschmidt, Helmut Tausendteufel and Wolfgang K. Härdle, July 2011.

046 "The Regulation of Interdependent Markets", by Raffaele Fiocco and Carlo Scarpa, July 2011.

047 "Bargaining and Collusion in a Regulatory Model", by Raffaele Fiocco and Mario Gilli, July 2011.

048 "Large Vector Auto Regressions", by Song Song and Peter J. Bickel, August 2011.

049 "Monetary Policy, Determinacy, and the Natural Rate Hypothesis", by Alexander Meyer-Gohde, August 2011.

050 "The impact of context and promotion on consumer responses and preferences in out-of-stock situations", by Nicole Wiebach and Jana L. Diels, August 2011.

051 "A Network Model of Financial System Resilience", by Kartik Anand, Prasanna Gai, Sujit Kapadia, Simon Brennan and Matthew Willison, August 2011.

052 "Rollover risk, network structure and systemic financial crises", by Kartik Anand, Prasanna Gai and Matteo Marsili, August 2011.

053 "When to Cross the Spread: Curve Following with Singular Control" by Felix Naujokat and Ulrich Horst, August 2011.

054 "TVICA - Time Varying Independent Component Analysis and Its Application to Financial Data" by Ray-Bing Chen, Ying Chen and Wolfgang K. Härdle, August 2011.

055 "Pricing Chinese rain: a multi-site multi-period equilibrium pricing model for rainfall derivatives" by Wolfgang K. Härdle and Maria Osipenko, August 2011.

056 "Limit Order Flow, Market Impact and Optimal Order Sizes: Evidence from NASDAQ TotalView-ITCH Data" by Nikolaus Hautsch and Ruihong Huang, August 2011.

057 "Optimal Display of Iceberg Orders" by Gökhan Cebiroğlu and Ulrich Horst, August 2011.

058 "Optimal liquidation in dark pools" by Peter Kratz and Torsten Schöneborn, September 2011.

059 "The Merit of High-Frequency Data in Portfolio Allocation" by Nikolaus Hautsch, Lada M. Kyj and Peter Malec, September 2011.

060 "On the Continuation of the Great Moderation: New evidence from G7 Countries" by Wenjuan Chen, September 2011.

061 "Forward-backward systems for expected utility maximization" by Ulrich Horst, Ying Hu, Peter Imkeller, Anthony Réveillac and Jianing Zhang.

062 "On heterogeneous latent class models with applications to the analysis of rating scores" by Aurélie Bertrand and Christian M. Hafner, October 2011.

063 "Multivariate Volatility Modeling of Electricity Futures" by Luc Bauwens, Christian Hafner and Diane Pierret, October 2011.

\section{SFB 649, Spandauer Str. 1, D-10178 Berlin} http:/ / sfb649.wiwi.hu-berlin.de

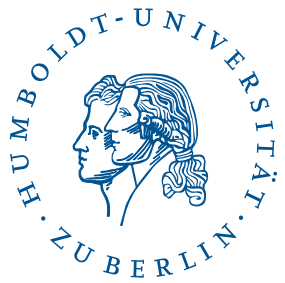




\section{SFB 649 Discussion Paper Series 2011}

For a complete list of Discussion Papers published by the SFB 649, please visit http://sfb649.wiwi.hu-berlin.de.

064 "Semiparametric Estimation with Generated Covariates" by Enno Mammen, Christoph Rothe and Melanie Schienle, October 2011.

065 "Linking corporate reputation and shareholder value using the publication of reputation rankings" by Sven Tischer and Lutz Hildebrandt, October 2011. 